\title{
ACCESS TO JUSTICE FOR THE WRONGFULLY ACCUSED IN NATIONAL SECURITY INVESTIGATIONS
}

\section{Jasminka Kalajdzic*}

Among the casualties in the 'war on terror' is the presumption of innocence. It is now known that four Canadians who were the subject of investigation by the RCMP and CSIS were detained and tortured in Syria on the basis of information that originated in and was shared by Canada. None has ever been charged with a crime. On their return home, all four men called for a process that would expose the truth about the role of Canadian agencies in what happened to them, and ultimately help them clear their names and rebuild their lives. To date, in varying degrees, all four men continue to wait for that "process." In this paper, I examine the access to justice mechanisms available to persons who are wrongfully accused of being involved in terrorist activities. Utilizing the case study of one of the four men, Abdullah Almalki, I explore the various processes available to him: (i) a complaint to the relevant domestic complaints bodies, the Security Intelligence Review Committee and the Commission for Public Complaints Against the RCMP; (ii) a commission of inquiry; and (iii) a civil tort claim. Due in large part to the role national security confidentiality plays in these mechanisms, all three models are found to be ineffective for those seeking accountability in the national security context.

Parmi les victimes de la "guerre contre le terrorisme» figure la présomption d'innocence. On sait maintenant que quatre Canadiens qui ont fait l'objet d'enquêtes par la GRC et le SCRS ont été détenus et torturés en Syrie suite à des renseignements ayant leur origine au Canada et partagés par le Canada. Nul d'entre eux n'a jamais été accusé de crime. À leur retour, tous les quatre hommes ont demandé un processus qui exposerait la vérité au sujet du rôle d'agences canadiennes dans ce qui leur est arrivé et qui éventuellement leur aiderait à rétablir leur réputation et refaire leur vie. À ce jour, à des degrés divers, tous les quatre hommes attendent toujours ce "processus". Dans cet article, jexamine les mécanismes d'accès à la justice à la disposition de personnes accusées faussement d'implication dans des activités terroristes. Par le biais de l'étude du cas de l'un des quatre hommes, Abdullah Almalki, jexplore les processus divers à sa disposition: (i) une plainte aux organismes pertinents qui reçoivent les plaintes au pays, le Comité de surveillance des activités de renseignements de sécurité et la Commission des plaintes du public contre la GRC; (ii) une commission d'enquête; et (iii) une réclamation en délit civil. En grande partie à cause du rôle que joue la confidentialité

* Faculty of Law, University of Windsor 
pour la sécurité nationale au sein de ces mécanismes, les trois modèles s'avèrent tous inefficaces pour ceux et celles qui recherchent la responsabilisation dans le contexte de sécurité nationale.

\section{INTRODUCTION}

By now, their stories are familiar: Maher Arar, Ahmed El Maati, Muayyed Nureddin and Abdullah Almalki, all Canadian citizens, all born in the Middle East, all detained and tortured overseas while under investigation by Canadian national security officials. All were interrogated by the same Syrian officials on the basis of information or questions that originated with Canadian agencies. Upon their return to Canada, "all called for a process which would expose the truth about the role of Canadian agencies in what happened to them, and which would help them clear their names and rebuild their lives." 1

Two Commissions of Inquiry, several complaints to the Royal Canadian Mounted Police [RCMP] and Canadian Security Intelligence Service [CSIS], and one settled civil action later, all four men, to varying degrees, continue to wait for the "process." Of the four, Arar has achieved the clearest vindication, having been exonerated in the clearest of terms by Commissioner Dennis O'Connor and compensated by the federal government pursuant to one of Commissioner O'Connor's recommendations. ${ }^{2}$ Yet even Arar continues to wage the battle to clear his name; he remains on the U.S. no-fly list, ${ }^{3}$ and his legal action against the American government over his rendition to Jordan then Syria was dismissed by a full panel of the Second Circuit Court of Appeals. ${ }^{4}$ More troubling, many

1 Backgrounder prepared on behalf of Amnesty International, the Canadian Arab Federation, the Canadian Council on American Islamic Relations, the Canadian Muslim Civil Liberties Association, and the International Civil Liberties Monitoring Group, Kerry Pither, "Questions we need answered by the Iacobucci Inquiry" (17 October 2008), online: Kerry Pither <http:// kerrypither.com/wp-content/uploads/2008/10/iacobucciquestions.pdf>.

2 Commission of Inquiry into the Actions of Canadian Officials Relating to Maher Arar, Report of the Events Relating to Maher Arar, Analysis and Recommendations (Minister of Public Works and Government Services, 2006) at 362 ["Arar Report"].

3 "Day asks U.S. to remove Arar from no-fly list following Rice's comments" CBC News (25 October 2007), online: CBC News <http://www.cbc.ca/canada/story/2007/10/25/day-arar. html>; Colin Freeze, "Arar is vindicated, but brothers feel victimized" Globe and Mail (8 November 2008).

4 On February 16, 2006 Judge David Trager of the U.S. District Court for the Eastern District of New York dismissed Arar's claims against John Ashcroft, Robert Mueller and Tom Ridge for their role in Arar's rendition to Syria to be tortured and arbitrarily detained. Judge Trager found that national security and foreign policy considerations prevented him from holding the officials liable for carrying out an extraordinary rendition even if such conduct violated treaty obligations or customary international law. On June 30, 2008 a divided panel of the Second Circuit Court of Appeals denied Arar's appeal on the basis that adjudicating his claim would interfere with foreign policy and state secrets: see Arar v. Ashcroft, 532 F.3d 157 (2nd Cir. 2008). In an unusual move, however, the full panel of the Second Circuit Appeals Court, acting sua sponte, announced on August 12, 2008 that as a result of a poll of the judges in active service, the case would be reheard en banc on December 9, 2008: On November 2, 2009, the Second Circuit Court of Appeals affirmed the district court's decision dismissing the case. All orders, decisions and briefs available online: Center for Constitutional Rights <http://ccrjustice.org/ourcases/ current-cases/arar-v.-ashcroft>. 
on both sides of the border continue to question his innocence, despite the clear language of exoneration contained in Commissioner O'Connor's report. In November 2008, a representative from the Hudson Institute, a Washington D.C. conservative think-tank, told a security intelligence conference in Ottawa:

\begin{abstract}
I don't think that we're convinced Maher Arar was vindicated or acquitted by your process. ... What you did was re-evaluate the treatment of Maher Arar and decide that procedural mistakes along the way had been made. That didn't vindicate him from the charge that he was involved in fundraising for terror.
\end{abstract}

People in Canada have turned the man into some sort of national hero, but if you expect the next administration to join you in sending him laurels, I think you're going to be mistaken. Even Barack Obama... is not going to go near that with a 10 -foot pole. [Mr. Arar will not have his name removed from the U.S. no-fly list] in my lifetime. ${ }^{5}$

The three other men have had even more limited justice. The Inquiry called to investigate the actions of Canadian officials in relation to El Maati, Almalki and Nureddin, was fraught with controversy and conducted almost entirely in camera. ${ }^{6}$ Nevertheless, in his report released publicly on October 21, 2008, Commissioner Frank Iacobucci concluded that Canadian officials had been "deficient" in various aspects of their investigations: inaccurate labels were used, questions were improperly sent to Syrian interrogators, and consular assistance was markedly below standard. ${ }^{7}$ Yet no clear declarations of innocence were made. In his opening paragraphs, Commissioner Iacobucci predictably confirmed the presumption of innocence, but stated that he was constrained by his terms of reference in making definitive findings about the merits of the terrorism allegations against the three men. ${ }^{8}$ Their quest for justice continues.

In this paper, I propose to examine the access to justice mechanisms available to persons who are wrongfully accused of being involved in terrorist activities. By "accused" I do not mean in the formal sense; much has been written about the Anti-Terrorism $A c t^{9}$ and the concomitant concerns over fair trial rights

5 Ian MacLeod, "Free Ride Into U.S. is Over, Analyst Says" Ottawa Citizen (1 November 2008).

6 See e.g. Campbell Clark, "Three men imprisoned in Middle East question secretive process of probe" Globe and Mail (10 August 2007) A11; and Thomas Walkom, "Arar case sheds light on 3 others" The Toronto Star (16 August 2007) A19. See also Affidavit of Hadayt Nazami sworn 2 October 2007, online: Iacobucci Inquiry <http://www.iacobucciinquiry.ca/pdfs/ documents/2007-10-02-2nd-Redacted-Application-Record.pdf $>$.

7 Internal Inquiry into the Actions of Canadian Officials in Relation to Abdullah Almalki, Ahmad Abou-Elmaati and Muayyed Nureddin, Report (Ottawa: Public Works and Government Services, 2008) at 35-39 ["Iacobucci Report"].

8 Ibid. at 30, 44. Throughout the Inquiry, Commissioner Iacobucci and Commission Counsel repeated that they were not investigating the investigators.

9 Bill C-36, An Act to amend the Criminal Code, the Official Secrets Act, the Canada Evidence Act, the Proceeds of Crime (Money Laundering) Act and other Acts, and to enact measures respecting the 
for persons charged with terrorism offences. ${ }^{10}$ Non-citizens who are accused of links to terrorism also may avail themselves of constitutional protections and the court system. ${ }^{11}$ Similarly, those people and organizations listed domestically or internationally have some ability (albeit limited) to become delisted. ${ }^{12}$ But what of those terrorism suspects who are neither formally charged, nor listed, nor subject to a security certificate? What remedies are available to those tainted - and damaged - by national security investigations?

I will look at this vexing problem by using the case study of Abdullah Almalki, a former client of the author, a man "accused" of terrorist links and whose human rights were violated as a consequence. ${ }^{13}$ I will explore the various access to justice mechanisms available to him: (i) a complaint to the relevant domestic complaints bodies, the Security Intelligence Review Committee (SIRC) and the Commission for Public Complaints Against the RCMP (CPC); (ii) a commission of inquiry; and (iii) a civil tort claim. While much has been written about commissions of inquiry generally, and the particular obstacles facing legal claims by torture survivors, little legal scholarship explores either the limits of the inquiry model for those seeking accountability in the national security context, or the utility of administrative review bodies for victims of a miscarriage of justice. Moreover, while each avenue has its inherent limitations and difficulties, all three share a common obstacle: national security confidentiality. The impact of state secrecy on an individual's attempt to achieve redress under all three options represents a unique barrier to justice that deserves particular attention.

Admittedly, Almalki's case is one of the most egregious examples of the impact of wrongful accusations on a continuum of harm. Others who are targeted by national security investigations may experience less pronounced stigma or less severe incursions into their daily lives, but face many ${ }^{14}$ of the same choices

registration of charities, in order to combat terrorism (assented to 18 December 2001, S.C. 2001, c. 41) ["ATA"]. Among the most cited legal commentaries on the ATA and Bill C-36, see Ronald J. Daniels et al., eds., The Security of Freedom: Essays on Canada's Anti-Terrorism Bill (Toronto: University of Toronto Press, 2001); Thomas Gabor, ed., The Views of Canadian Scholars on the Impact of the Anti-Terrorism Act, Department of Justice (31 March 2004), online: Department of Justice Canada <http://canada.justice.gc.ca/en/ps/rs/rep/2005/rr05-1/rr05-1.pdf>.

10 Kent Roach, "Did September 11 Change Everything? Struggling to Preserve Canadian Values in the Face of Terrorism" (2002) 47 McGill L.J. 893.

11 Immigration and Refugee Protection Act, S.C. 2001, c. 27, ss. 77-81. But see Hamish Stewart, "Is Indefinite Detention of Terrorist Suspects Really Constitutional?" (2005) 54 U.N.B.L.J. 235 for a comprehensive critique of the shortcomings of the security certificate regime.

12 The listing process has a number of safeguards. Application can be made for review of the decision to list, first to the Minister of Public Safety and then to the Federal Court. There is a specific procedure to protect those who may be mistakenly identified as a listed entity. As well, the list of entities must be reviewed two years after its establishment and every two years thereafter, although to date, no listed entity has been delisted pursuant to the bi-annual review. See s. 83.05(1) of the Criminal Code, R.S.C. 1985, c. C-46. For a discussion of the flaws in the listing mechanism, see E. Alexandra Dosman, "For the Record: Designating 'Listed Entities' for the Purposes of Terrorist Financing Offences at Canadian Law” (2004) 62 U.T.Fac.L.Rev. 1.

13 The author was counsel for Abdullah Almalki before the Iacobucci Inquiry, but does not represent him in his civil action against the Crown.

14 The exception being a commission of inquiry; given the highly discretionary and ad hoc nature of inquiries explored in Part V of this paper, it is doubtful that a person or group who has 
regarding access to justice mechanisms should they seek exoneration or reparations. In this way, the answers to the questions posed in this essay may be of moment not just to the four men whose cases have received considerable public attention, but will also be significant for the hundreds of others who assert that they have been victimized by flawed intelligence activities. ${ }^{15}$

Ultimately, the availability of remedies for those caught in the snares of terrorism investigations is a crucial issue not just for the claimants themselves. Access to justice for those described by Kent Roach and Gary Trotter as "collateral damage" 16 in the fight against terrorism has important implications for our very conceptions of the "just society," and for the success of the fight itself. Failure to heed the wrongfully accused's call to account will "erode the high ground that democracies that only punish the guilty should have in the war against terror," 17 and condemns the wrongfully accused indefinitely.

\section{ACCESS TO JUSTICE PARADIGM}

Access to justice enjoys considerable play in legal and political discourse. It is a dominant theme in law reform initiatives and government programs. ${ }^{18}$ It has been posited as a human right, ${ }^{19}$ and confirmed as a constitutional right. ${ }^{20}$ In its more limited conception, it refers fundamentally to the range of institutional arrangements that enable people to access the justice system for the vindication of their rights. ${ }^{21}$ More broadly, it refers to participation in every institution "where law is debated, created, found, organized, administered, interpreted and applied." ${ }^{22}$ It has generated a tremendous body of legal literature, yet its content

experienced less severe repercussions would be able to rally sufficient public and political support for a commission of inquiry to be struck.

15 Determining the precise number of people along the continuum is not possible. Various sources provide some order of magnitude; in its 2005 report entitled "Presumption of Guilt", online: Canadian Council on American-Islamic Relations < http://www.caircan.ca/downloads/POG08062005.pdf>, CAIR-CAN suggested that 8 out of 100 Canadian Muslims had been visited by RCMP, CSIS, or other police agents, and that $23 \%$ of the interviews occurred at a place of employment. A recent article in USA Today provides different benchmarks; over 1,000,000 people are currently on the U.S. terrorist watch list, the majority foreigners. Since 2005,830 'redress requests' have been made seeking removal from the list. See Peter Eisler, "Terrorist Watch List Hits 1 Million” USA Today (10 March 2009), online: USA Today <http://www. usatoday.com/news/washington/2009-03-10-watchlist_N.htm>.

16 "Miscarriages of Justice in the War Against Terror" (2004-2005) 109 Penn St. L. Rev. 967. Roach and Trotter do not endorse use of the descriptor.

17 Ibid. at 1041.

18 Michael Trebilcock, Report of the Legal Aid Review 2008, online: Ministry of the Attorney General <http://www.attorneygeneral.jus.gov.on.ca/english/about/pubs/trebilcock/legal_aid_ report_2008_EN.pdf>.

19 Francesco Francioni, ed., Access to Justice as a Human Right (Oxford: Oxford University Press, 2007).

20 B.C.G.E.U. v. British Columbia (A.G.), [1998] 2 S.C.R. 214 at paras. 25-26 ["We have no doubt that the right to access to the courts is under the rule of law one of the foundational pillars protecting the rights and freedoms of our citizens"].

21 Faisal Bhabha, "Institutionalizing Access-to-Justice: Judicial, Legislative and Grassroots Dimensions" (2007) 33 Queen's L.J. 139 at 141.

22 Roderick A. Macdonald, "Access to Justice in Canada Today: Scope, Scale and Ambitions" in 
remains fundamentally contested. ${ }^{23}$ Few would deny the importance of access to justice as a foundational principle in a liberal democracy, but how such a principle manifests itself "on the ground" elicits anything but unanimity.

Access to justice in this paper refers primarily to the applicable legal norms and institutions that facilitate access to law and the legal process. ${ }^{24}$ "Justice," more broadly defined, also includes considerations of the procedural, substantive, and symbolic components identified most often with Professor Roderick Macdonald. That is, access to justice must be considered in its pluralistic and multidimensional forms: as a matter of procedure, it is about both gaining access to decision-making institutions and to procedural fairness once engaged within them; as a matter of substance, it must produce effective remedies that make right the imbalance between national security and human security; and as a matter of social symbolism, it asks whether the legal system empowers and engages its citizenry, particularly those with disparate social power and 'otherness. ${ }^{25}$ Elements of this more holistic vision of access to justice will also be considered, though it is beyond the scope of the paper to examine fully all sites where "law is debated, created, found, organized, administered, interpreted and applied"26 from the perspective of the wrongfully accused.

That I focus my analysis on the availability of access to justice mechanisms for those targeted in anti-terrorism investigations is not to suggest that perfect or even adequate access to justice exists for those who are accused and acquitted of traditional criminal offences, or who are wrongfully convicted of such offences. It is arguable that publicity surrounding a criminal charge in itself permanently harms an individual, even if the charges are ultimately dismissed. The recent recognition by the Supreme Court of Canada (SCC) of the tort of negligent investigation ${ }^{27}$ may hold little promise of meaningful justice given the high threshold that must be met to establish the tort, in addition to the usual litany of economic barriers that litigants face in our civil justice system. Moreover, at times advocates for the wrongfully convicted, have claimed that even a verdict of 'not guilty' stops short of complete exoneration and is insufficient to completely dispel the stigma and shame which encumber their clients. ${ }^{28}$ Nevertheless, in the

Julia Bass et al., eds., Access to Justice for a New Century (Law Society of Upper Canada, 2005) 19 at 23.

23 See e.g. Marc Galanter, "Access to Justice as a Moving Frontier" in Bass, supra note 22, at 147161. See also Faisal Bhabha, "Book Review: Access to Justice as a Human Right" (2008) 24 W.R.L.S.I. 85 at 86.

24 The same definitional approach is used by Fionnuala Ní Aoláin, "The Individual Right of Access to Justice in Times of Crisis: Emergencies, Armed Conflict, and Terrorism" in Francesco Francioni, ed., Access to Justice as a Human Right (Oxford: Oxford University Press, 2007) 57 at 58.

25 Macdonald, supra note 22.

26 Ibid. at 6.

27 Hill v. Hamilton-Wentworth Regional Police Services Board, 2007 SCC 41.

28 Justice Robins made this point in his report to the Attorney General recommending compensation for Steven Truscott, who was acquitted but not declared factually innocent, and thus would never be in a position to prove he did not commit the crime in question; see Hon. Sydney Robins, Advisory Opinion on the Issue of Compensation (March 28, 2008) at 29, online: Ministry of The Attorney General <http://www.attorneygeneral.jus.gov.on.ca/english/about/ pubs/truscott/section5.asp\#15>. 
criminal law context the accused has constitutionally entrenched rights to a fair trial, to Charter protections and clearly defined rules of evidence, to Legal Aid, and to the presumption of innocence. Ultimately, in our legal system, an acquittal means something - the next best thing to a declaration of innocence. ${ }^{29}$

My central claim here, however, is that obtaining access to justice in the anti-terrorism context is peculiarly problematic. National security investigations rarely lead to criminal charges. Nevertheless, pervasive concerns with terrorism "obstruct access to justice at the domestic level as states increasingly justify encroachments on civil liberties in defence of national security." ${ }^{30}$ While the legality of certain anti-terrorism measures remains suspect even where bona fide charges of terrorism with a sound evidentiary basis are laid, ${ }^{31} \mathrm{I}$ am particularly concerned here with those individuals who are the terrorism investigation equivalents of the wrongfully convicted: wrongly accused by government officials publicly and/or in communications with foreign agencies as associated with terrorism, adversely affected in their employment or businesses by heightened scrutiny, harassed by border guards, police officers or intelligence agents, detained on the basis of those allegations, or, in the most extreme cases, tortured. In this way, I do not adhere to the strict positivist interpretation of a miscarriage of justice proffered by Roach and Trotter in their study. ${ }^{32}$ While they argue for a conceptualization of a miscarriage of justice that includes all deprivations of liberty, my conception of a miscarriage of justice is broader, and captures the experience of those who are not detained directly by Canadian authorities (if at all) but who nevertheless are harmed by the terrorist label. Like Roach and Trotter, I presuppose the factual innocence of at least some terrorism investigation targets ${ }^{33}$ and from there, examine the adequacy of available legal processes. That is, I ask to what extent do existing mechanisms provide redress for victims of a miscarriage of justice in the national security context? Are the mechanisms substantively adequate? Can the factually innocent clear their names?

29 Referring to Steven Truscott, for example, lawyer James Lockyer has said that his client "got the highest rank of acquittal, the highest rank of innocence you can get:" Tracy Tyler, "Truscott acquittal weighed" The Toronto Star (29 August 2007). See also Peter MacKinnon, "Costs and Compensation for the Innocent Accused” (1988) 67 Can. Bar Rev. 489 and H. Archibald Kaiser, "Wrongful Conviction and Imprisonment: Towards an End to the Compensatory Obstacle Course" (1998) 9 Windsor Y.B. Access Just. 139, both of whom argue that a discharge or acquittal are equivalent to innocence in our system of justice.

30 Bhabha, supra note 23 at 87.

31 Certainly, the use of torture could never be justified, whatever the circumstances or the allegations against the accused. See Convention against Torture and Other Cruel, Inhuman or Degrading Treatment or Punishment, U.N.Doc. A/39/51 (1989), and Criminal Code, supra note 12 at s. 269.1.

32 "[O] ur definition of a miscarriage of justice will not engage the legality under either international or domestic law of the definition of who is an enemy combatant or who is an inadmissible alien because of involvement with a terrorist group. Rather, our focus will be on the injustice of detaining a person who is innocent under the existing statutory definition of an enemy combatant or an inadmissible alien." Supra note 16 at 973.

33 Ibid. at 1037. Indeed, as Roach and Trotter argue persuasively, the risks of a miscarriage of justice in the national security sphere are perhaps higher than in traditional criminal law enforcement, in part because of the prevalent use of intelligence as opposed to probative evidence. 


\section{CASE STUDY: ABDULLAH ALMALKI}

Here's the deal. Everybody would like to believe that we have an array of choices that are good choices and bad choices. But we're going to a dance where every girl is ugly, okay. They're all ugly. And all we can do is get the least ugly girl to dance with. ${ }^{34}$

Jack Hooper, Director-General, CSIS (May 26, 2007)

Almalki was first contacted by CSIS agents in 1998. He agreed to their request for meetings and answered their questions without a lawyer present on two occasions in 1998, once in 2000 and a fourth time less than a week after September 11, 2001..$^{35}$ He was asked about his export-import business, what electronic equipment he sold, to whom, and his knowledge of other Canadian Muslim men. CSIS shared information about Almalki with the RCMP and various foreign intelligence agencies, including the U.S. Central Intelligence Agency (CIA) and the Federal Bureau of Investigation (FBI). ${ }^{36}$

In late September 2001, a multi-agency task force named Project A-O Canada was established to investigate suspected terrorists. Members from different units within the RCMP as well as from CSIS and other police agencies were seconded to the project. Project A-O Canada's mandate was, in order of priority, prevention, intelligence, and criminal prosecution. Almalki was a main target of Project A-O Canada. In the months following the establishment of Project A-O Canada, officers aggressively pursued him as a suspected terrorist. Among other things, these officers:

(a) followed Almalki and his wife whenever they traveled by car;

(b) installed a camera across the street from their home to monitor the family and any visitors to the home;

(c) sent a fax to RCMP liaison officers in Islamabad, Rome, Delhi, Washington, London, Berlin and Paris on October 2, 2001 identifying Almalki as an "important member" of al Qaeda;

(d) sent letters to law enforcement agencies in several countries, including Syria, on October 4, 2001, providing biographical data about Almalki and other Canadians and requesting any intelligence that might surface on them;

(e) authorized an October 31, 2001 request to U.S. Customs Service to issue a TECS [Treasury Enforcement Com-

34 Michelle Sheppard, "Spy was sent to 'ugly' spots" The Toronto Star (26 May 2007) A1.

35 Chronology of public information relating to the cases of Messrs. Almalki, El Maati and Nureddin, online: Kerry Pither <http://kerrypither.com/wp-content/uploads/2008/10/chronologyfinal. pdf $>$ at $1,2,7$.

36 Iacobucci Report, supra note 7 at 194-197. 
munications System] lookout for Almalki and members of his family, in which they were described as "Islamic extremist individuals suspected of being linked to the al Qaeda terrorist movement;"

(f) executed a search warrant on Almalki's home in Ottawa, pursuant to which they seized all of his business records, and in which they claimed to have found "weapons;" ${ }^{37}$

(g) shared their entire Supertext database, without caveats, with U.S. agencies (presumably, the FBI and CIA). The three CDs contained all of Project A-O Canada's intelligence, including documents and information about $\mathrm{Al}$ malki that had not been vetted for accuracy or relevance; and

(h) shared information with U.S., Syrian and other foreign agencies about Almalki, including sending questions directly to Syrian interrogators to be put to Almalki, despite their knowledge of the likelihood of torture. ${ }^{38}$

Despite the length, intrusiveness, and scope of the investigation into Almalki's life, business, and acquaintances, no charges were ever laid against him by Canadian authorities. FBI investigators refused to launch a criminal investigation into Almalki's activities. ${ }^{39}$

On his way to join his parents and visit family in Syria in early May, 2002, Almalki was detained at Damascus Airport. A little over five months earlier, another Canadian, El Maati, was also detained at the same airport. Like El Maati before him, and Arar and Nureddin after him, Almalki was taken to the Palestine Branch of the Syrian Military Intelligence and was repeatedly tortured, interrogated and forced to sign documents he was not permitted to read. All four men were held in dark, underground cells, measuring three by six by seven feet. Almalki's tenure was the longest: 482 days in solitary confinement, in a cell known to prisoners as "the grave." ${ }^{40}$

The Arar Inquiry determined that the RCMP sent questions to Syrian Military Intelligence to use in their interrogations of Almalki. This evidence was not disclosed in the course of the public hearings. Throughout the Inquiry, government counsel fought vigorously to prevent Commissioner O'Connor from disclosing the January 2003 questions and cover letter that had been delivered by Consul Leo Martel to Syrian Military Intelligence. The Attorney-General only withdrew his position that the information was subject to a claim of national security confi-

37 Almalki was told by Syrian interrogators that weapons had been found at his home. The Iacobucci Report provides the first disclosure of the "weapons" in question: two switchblades Ibid. at 202.

38 Ibid. at 193-201, 403-404, 410-413.

39 Arar Report, supra note 3, Addendum, online: Library and Archives Canada <http://epe.lacbac.gc.ca/100/206/301/pco-bcp/commissions/maher_arar/07-09-13/www.ararcommission. ca/eng/2007-08-08-addendum.pdf> at 103. ["Project A-O Canada was not successful in convincing the FBI to institute a criminal investigation."].

40 Iacobucci Report, supra note 7 at 271. 
dentiality after the hearings had concluded, when counsel for the non-government participants (including Arar, the intervenor organizations, and belatedly, Almal$\mathrm{ki}^{41}$ ) were no longer able to explore the circumstances surrounding the decision to send questions and the impact of the questions on Almalki and Arar. ${ }^{42}$

Commissioner Iacobucci found that both the sharing of the Supertext database with U.S. officials in April 2002, and the sending of questions in January 2003, "resulted indirectly in mistreatment of Mr. Almalki and were deficient in the circumstances," ${ }^{43}$ and that the "mistreatment" amounted to torture. ${ }^{44} \mathrm{As} \mathrm{Al}-$ malki had claimed from the time he was released from custody in Syria, his interrogations were based on information that could only have originated in Canada; Commissioner Iacobucci concluded that "it is reasonable to infer that the documents provided in the Supertext database, or information from those documents, made their way into the hands of Syrian officials, and were then used by them, together with other information, to interrogate Mr. Almalki in Syria." ${ }^{45}$

Although never charged with an offence in either Canada or the United States, in late 2003, after 18 months in detention without charge, Almalki was charged under Article 278 of the Syrian Penal Code. ${ }^{46}$ In July 2004, the Syrian Supreme State Security Court, a court whose trials fall far short of international standards for fair trials, ${ }^{47}$ acquitted Almalki. ${ }^{48}$ Nevertheless, doubts about his innocence persist.

As in the case of Arar and El Maati, unnamed Canadian officials used the media to accuse Almalki of links to al Qaeda. In October 2003, senior unnamed Canadian government officials told Canadian Television (CTV) News that Al-

41 Almalki's initial request for standing was denied by Commissioner O'Connor: see Ruling on Standing and Funding, Arar Report, Factual Background, Vol. II, Appendix 3(B). As government witnesses increasingly referred to Almalki, El Maati, and Nureddin as suspected terrorists in their public testimony, Commissioner O'Connor accepted that the men's reputational interests were sufficient to trigger participation rights and he awarded them limited standing. Arar Report, supra note 2, Factual Background, Vol. II, Appendix 3(E).

42 Arar Report, supra note 2 at 303.

43 Iacobucci Report, supra note 7 at 398.

44 Ibid. at 406.

45 Ibid. at 409.

46 This provision of the Syrian Penal Code deals with taking action or making a written statement or speech which could endanger the state or harm its relationship with a foreign country, or expose it to the risk of hostile action by that country. For a further description of Article 278, see "Urgent Action Update: Syria - Prisoners of Conscience/Fear of Torture/Incommunicado Detention" Amnesty International (21 December 2006), online: The Syrian Human Rights Committee <http://www.shrc.org/data/aspx/D8/2978.aspx>.

47 According to the Syrian Human Rights Committee, the Supreme State Security Court (SSSC) is "an extra-ordinary legal structure whose sentences cannot be appealed or contested, and [which] relies in passing its sentences on security authorities' minutes and reports, which are normally extracted from suspects forcefully and under torture. The SSSC is also renowned for committing outrageous contraventions and violations in respect to [sic] holding sessions and allowing defendants from defending themselves" (SHRC 2006 Annual Report, online: Syrian Human Rights Committee <http://www.shrc.org/data/aspx/ANNUALREPORT2006.aspx> at ch. 6. See also "Far From Justice: Syria’s Supreme State Security Court" Human Rights Watch (February 2009), online: Human Rights Watch <http://www.hrw.org/en/reports/2009/02/23/ far-justice- $0>$.

48 Iacobucci Report, supra note 7 at 248. 
malki was one of four Canadians linked to an al Qaeda cell. ${ }^{49}$ In November 2003, unnamed Canadian officials described Almalki as "the main target" of terrorism investigations to the Ottawa Citizen..$^{50}$ Most recently, during the press conference on the date of the release of Commissioner Iacobucci's report, and in numerous media interviews thereafter, Minister of Public Safety, Stockwell Day referred reporters specifically to paragraph 42 of the Attorney-General's final submissions, in response to questions about the status of national security investigations regarding Almalki. Paragraph 42 of the document reads in part,

...Canada had credible information that the activities of Mr. Almalki posed a threat to the security of this country. ... Mr. Almalki associated with known Islamist extremists in Canada and abroad, including senior members of al Qaeda. He is believed to have served as a procurement officer for that organization. $^{51}$

Importantly, Minister Day failed to point out that the paragraph, which was not even couched in the usual language of allegations, was contained in a document that did not constitute evidence, and that was vigorously contested by counsel for Almalki.

None of the evidence that might exist in support of the government's allegations has ever been presented to Almalki or his counsel, precluding him from challenging the allegations or questioning the propriety of the ways in which he was targeted by Canadian officials. Despite submissions to the Commissioner that he should not "simply repeat the Government's unproven, untested and libelous allegations against the three men" in his final report, ${ }^{52}$ an entire chapter was devoted to the summary of those allegations, ${ }^{53}$ with only two paragraphs cautioning that nothing stated in the report should be taken as an indication that the government's allegations are founded. ${ }^{54}$ Whether the cautionary language is sufficient to rebut the aura of guilt is questionable; Commissioner O'Connor found that in terrorism investigations, improper and unfair labels in a written document carry an air of authority: "Statements made by police officers tend to be taken at face value" and "have a way of sticking to an individual, [...] becoming the accepted fact or wisdom." ${ }^{\text {5 }}$ This is perhaps even more true with statements repeated in an official report by a commission of inquiry.

49 "The case of Maher Arar takes more twists and turns" CTV News (23 October 2003). See description of leak in Kerry Pither, Dark Days: The Story of Four Canadians Tortured in the Name of Fighting Terror (Toronto: Viking Press, 2008) at 293-295.

50 Juliet O’Neill, "Canada’s Dossier on Maher Arar" Ottawa Citizen (8 November 2003) A1.

51 Closing Submissions of the Attorney General of Canada (20 June 2008), online: Iacobucci Internal Inquiry <http://www.iacobucciinquiry.ca/pdfs/documents/2008-06-20-AG-FINALen.pdf> at para. 42.

52 Joint Final Submissions by Abdullah Almalki, Ahmad El Maati \& Muayyed Nureddin (20 June 2008), online: Iacobucci Internal Inquiry <http://www.iacobucciinquiry.ca/pdfs/ documents/2008-06-20-final-submissions-almalk-el-maati-nureddin-en.pdf> at para. 13.

53 Iacobucci Report, supra note 7 at c. 5.

$54 \mathrm{Ibid}$. at 43.

55 Arar Report, supra note 2 at 25. 
Miscarriages of justice greet Almalki, therefore, on numerous levels. First, he is targeted by a national security investigation for associations with others and for allegedly suspicious business transactions. Though not formally charged nor permitted to test the intelligence and answer his accusers, he is labeled an "Islamic extremist" and a "Bin Laden associate." The label becomes evidence as quickly as it is circulated around the world, in what Guittet and others describe as the blurring of the line between intelligence data and probative evidence to the advantage of so-called "national security imperatives." ${ }^{26}$ This injustice leads to the next, more profound violation of Almalki's human rights, when the intelligence qua evidence is used to detain, interrogate and torture him in Syria. According to Hooper's distasteful metaphor for the trade-off between security and rights quoted at the outset of this Part, sharing information with human rights abusing regimes and sacrificing the rights of suspected terrorists is a necessary evil, and thereby condones Almalki's mistreatment. When not permanently condemned to the torture chamber, he is then perpetually condemned through repeated allegations of terrorism not only via media leaks, but also by pronouncements of Ministers and in a Commissioner's report. How, then, to unravel the injustice?

Counsel's final submissions to the Commission alluded to the poverty of access to justice mechanisms. In the course of pressing the Commissioner to find categorically that labels attached to the three men by Canadian officials were grossly inaccurate, unfair, and misleading, counsel wrote:

There is no other forum in which Messrs. Almalki, El Maati and Nureddin will be able to clear their names. Absent a criminal charge, the men will not be afforded the opportunity to know and meet the case against them. Civil litigation is unlikely to provide them access to justice in light of the government's consistent overuse of national security confidentiality claims. ...

Commissioner Iacobucci has a singular opportunity to expose the ways in which these three Canadian citizens were mislabeled and mischaracterized, and identify the deficiencies in the investigations which led to the sharing of inaccurate and misleading information, and ultimately, to their detention and mistreatment abroad. We urge the Commissioner to provide Messrs. Almalki, El Maati and Nureddin with the answers - and the justice - they deserve. ${ }^{57}$

The extent to which the inquiry model can serve effective access to justice will be

56 Emmanuel-Pierre Guittet, "Miscarriages of Justice and Exceptional Procedures in the "War against Terrorism”" (2008) Centre for European Policy Studies Special Report 1 at 2. See also Martin Scheinin, Report of the Special Rapporteur on the promotion and protection of human rights and fundamental freedoms while countering terrorism, (4 February 2009) A/HRC/10/3, online: <http://image.guardian.co.uk/sys-files/Guardian/documents/2009/03/09/ahrc.pdf> at 8.

57 Joint Final Submissions, supra note 52 at paras. 11-12. 
examined in Part $\mathrm{V}$ of this paper. Two other main options present themselves: a civil torts claim, and complaints to the administrative bodies that provide oversight of Canada's national security investigations.

\section{ADMINISTRATIVE ACCESS TO JUSTICE: COMPLAINTS TO SIRC AND THE CPC}

If individuals have complaints regarding actions of law enforcement and security intelligence personnel, we have robust independent review and accountability mechanisms in place. They are there to be used. ${ }^{58}$

Ministers Anne McLellan and Irwin Cotler (Nov. 2005)

Among the "robust independent review and accountability mechanisms" referred to by Anne McLellan and Irwin Cotler in their joint statement before the Senate Special Committee on the Anti-terrorism Act and the House of Commons Subcommittee on Public Safety and National Security, two will be canvassed here: the CPC and SIRC.

\section{A. CPC (Commission for Public Complaints Against the RCMP)}

The CPC was created in 1988 as an independent agency to provide civilian review of the RCMP's policing activities. ${ }^{59}$ The CPC's jurisdiction is relatively broad; it may examine any complaint concerning the conduct, in the performance of any duty or function under the RCMP Act or the Witness Protection Program Act, of any RCMP member, whether or not the complainant is affected by the subject-matter of the complaint. ${ }^{60}$ Investigations can be triggered in one of three ways: (i) a direct complaint by a civilian to the $\mathrm{CPC}$; ${ }^{61}$ (ii) a request for a review of a complaint made to the RCMP, ${ }^{62}$ or (iii) a Chair-initiated complaint. ${ }^{63}$ Commissioners retain wide discretion with respect to complaints made directly to the CPC; they may direct that no investigation of a complaint be commenced or that an investigation be terminated if, in the Commissioner's opinion,

(a) the complaint is one that could more appropriately be dealt with, initially or completely, according to a procedure provided under any other Act of Parliament;

58 Joint Statement by the Hon. Anne McLellan, Deputy Prime Minister and Minister of Public Safety and Emergency Preparedness \& the Hon. Irwin Cotler, Minister of Justice and Attorney General of Canada, online: Department of Justice <http://www.justice.gc.ca/eng/news-nouv/ spe-disc/2005/doc_31726.html>.

59 Royal Canadian Mounted Police Act. R.S., c. R-9, s. 45.29 ("RCMP Act”).

60 Ibid. at s. 45.35 .

61 Ibid. at s. $45.35(1)$.

62 Ibid. at s. 45.41.

$63 \mathrm{Ibid}$. at s. 45.37. In 2007-2008, eight Chair-initiated complaints were investigated, representing a marked increase over previous years. The increase reflects the Chair's stated objective of moving beyond its traditionally reactive role to a more proactive one targeting systemic issues. See 20072008 Annual Report, online: < http://www.cpc-cpp.gc.ca/prr/anr/2007-2008-eng.aspx>. 
(b) the complaint is trivial, frivolous, vexatious or made in bad faith; or

(c) having regard to all the circumstances, investigation or further investigation is not necessary. ${ }^{64}$

Even if launched, investigations and reviews of RCMP conduct are compromised by the CPC's restrictive mandate. The RCMP Act does not confer powers of subpoena on the CPC; neither documents nor witnesses can be compelled. The $\mathrm{CPC}$ is not mandated to take evidence under oath, nor does it have the legislative authority to complain about policies, practices, or guidelines followed by the RCMP. ${ }^{65}$ In 2003, the Auditor General found that "the Commission for Public Complaints Against the RCMP, in comparison to the Security Intelligence Review Committee, does not undertake reviews aimed at systematically determining compliance with the law, nor does its mandate provide for unrestricted access to all information." 66

The Chair of the CPC harbours no illusions about the capacity of his agency to provide effective oversight and to ensure accountability in the conduct of policing activity. In December 2008, in his opening remarks marking the $20^{\text {th }}$ anniversary of the CPC, Chairman Paul E. Kennedy described the Commission as providing "inadequate civilian oversight," due primarily to the incongruence between its powers of review and the intrusiveness of the powers held by the body over which it exercises review. ${ }^{67}$ Indeed, since 2005 the overarching objective of the CPC has been the "urgent need for stronger and more effective civilian oversight of the RCMP." 68

The CPC has done considerable work with Taser-related and other in-custody death cases, ${ }^{69}$ but appears to have had little involvement with complaints concerning national security investigations. One exception is its review of Project Thread. The 2003 investigation of Ottawa Business College led to the arrest of 23 Muslim students who the RCMP and Immigration officials suspected of possessing fraudulent immigration documents, but who were described to the media as posing threats to national security. The RCMP subsequently confirmed that there was "absolutely no evidence to suggest that there is any terrorist threat

64 Ibid. at 45.36(5).

65 See Presentation before Arar Commission (17 November 2005), online: Commission for Public Complaints against the RCMP <http://www.cpc-cpp.gc.ca/nrm/spe/arc/2005/20051117-eng. aspx>.

66 Ibid.

67 Online: Commission for Public Complaints against the RCMP < http://www.cpccpp.gc.ca/nrm/spe/2008/20081201-eng.aspx>. Mr. Kennedy repeated these views before the Parliamentary Committee on Public Safety on March 5, 2009. [Standing Committee on Public Safety and National Security, Evidence, 40th Parl. 2nd sess., No. 008 (5 March 2009), online: $<$ http://www2.parl.gc.ca/HousePublications/Publication.aspx?DocId=3723563\&Language=E \&Mode $=1 \& \operatorname{Parl}=40 \&$ Ses $=2>$.

68 News Release: "Proposals For New Civilian RCMP Oversight Model Emerge at CPC 20th Anniversary Conference" (1 December 2008), online: Commission for Public Complaints against the RCMP <http://www.cpc-cpp.gc.ca/nrm/nr/2008/20081201-eng.aspx>.

69 See e.g., the two Special Reports issued in 2007-2008, online: Commission for Public Complaints against the RCMP <http://www.cpc-cpp.gc.ca/prr/rep/sir/index-eng.aspx>. 
anywhere in this country related to this investigation." ${ }^{70}$ The CPC concluded that the Force did not engage in racial profiling on a very narrow definition of the term, and determined that no apology by the Force was warranted since it did not control the immigration detention process where the allegations of terrorism were originally made. The CPC's limited jurisdiction in this instance is indicative of a larger problem faced by the wrongfully accused: an effective access to justice mechanism must provide access to all of the relevant information and the power to review the conduct of every government agency or department tasked with a national security mandate. The necessity of abandoning a compartmentalized approach to review and accountability based on rigid departmental boundaries is driven by the very nature of national security work in Canada: a network of governmental entities encouraged to share information and cooperate in a comprehensive approach to security.

Maher Arar also complained to the CPC; its investigation of Arar's complaint was suspended during the currency of the Inquiry and then terminated immediately following the release of Commissioner O'Connor's report. ${ }^{71}$ Given that the powers of the Arar Commission were much broader than those afforded to the $\mathrm{CPC}$ under its enabling legislation, the decision to terminate the investigation flows predictably from the Commissioner's powers under s. 45.36(5)(a) of the RCMP Act. ${ }^{72}$ The same outcome likely awaits Almalki's complaint, launched in August $2005,{ }^{73}$ and held in abeyance pending the report of the Iacobucci Inquiry.

The determination of the propriety of specific steps taken by unnamed officials in the course of a multi-year investigation would, in any event, yield piecemeal justice. For those wrongfully accused of terrorism-related offences, there is no one event that can be scrutinized. Indeed, many are not even aware of the specific events that have adversely affected them; this lack of transparency significantly compromises the usefulness of a complaints process. ${ }^{74} \mathrm{~A}$ series of decisions, assumptions, and speculations made by innumerable, faceless officials, in fulfillment of the primary mandate to prevent a future attack, "lead to condemnation through allegations of terrorism rather than proof." 75 A review body

70 Chair's Final Report - Incident Related to National Security (28 February 2006), online: Commission for Public Complaints against the RCMP <http:/www.cpc-cpp.gc.ca/prr/rep/rev/ chair-pre/securi-finR-060228-eng.aspx>.

71 Commissioner O'Connor further noted that the CPC cannot investigate CSIS; similarly, SIRC cannot investigate any agency or government department beyond CSIS. There is no mechanism available to address the integrated nature of national security investigations: Arar Report, supra note 2 at 277 .

72 Section 45.36(5) (a) allows the Commissioner to terminate an investigation if "the complaint is one that could more appropriately be dealt with, initially or completely, according to a procedure provided under any other Act of Parliament."

73 Letter dated 19 August 2005 from Paul Copeland to Shirley Heafey [on file with author].

74 Commission of Inquiry into the Actions of Canadian Officials in Relation to Maher Arar, Policy Review: A New Mechanism for the RCMP's National Security Activities (Ottawa: Public Works and Government Services, 2006) at 500. In this paper, however, I am concerned with precisely the opposite problem: the wrongfully accused know that they are the subject of an investigation because of the ramifications of the labels and shared intelligence for their liberty and security interests.

75 Guittet, supra note 56 at 6. 
mandated to review an officer's "performance of any duty or function" under the $R C M P A c t^{76}$ is incapable of unraveling the net of suspicion that entangles such cases. Coupled with the inability to summons documents, gain access to Cabinet confidences, or compel witnesses, an investigation by CPC yields no meaningful justice.

The CPC's process meets none of the objectives of the access to justice paradigm proffered at the outset of this paper. While direct access to the agency promises at least modest procedural justice, the participation rights of complainants, and the circumscribed procedural powers of the agency itself, render access to justice largely hollow. Moreover, the absence of compensation limits the substantive quality of this accountability mechanism.

\section{B. SIRC [Security Intelligence Review Committee]}

In 1977, prompted by allegations of unlawful and improper behaviour by security intelligence officers within the RCMP, the government established the Commission of Inquiry Concerning Certain Activities of the RCMP, chaired by Mr. Justice David McDonald. ${ }^{77}$ The Commission concluded that, due to the differences between security intelligence work and police work, the government ought to separate the two functions of the RCMP. As a result, CSIS was created, and SIRC was established to review the activities of the new intelligence agency. ${ }^{78}$

SIRC consists of a committee appointed by the government and supported by security-cleared staff. Unlike the CPC, SIRC has access to sensitive CSIS documents, including documents protected by national security confidentiality. SIRC does not have access, however, to documents that are considered to constitute Cabinet confidences, including CSIS' Security Intelligence Reports which are provided to the Governor-in-Council for, among other things, the terrorist listing process. SIRC's primary function is to review CSIS' past practices and provide advice to CSIS and the bodies of government that direct it, regarding potential modifications to policy and procedure. ${ }^{79}$ SIRC's second role is to investigate complaints. Complaints to SIRC may be made in writing directly to SIRC by individuals who claim to have been harmed by CSIS activities or who were denied security clearance. Once the complaint is received, SIRC staff conducts an initial review to establish whether the complaint falls within SIRC's jurisdiction. If jurisdiction is established, one or more Committee members investigate the complaint through a quasi-judicial hearing with the assistance of staff and a security cleared lawyer. The complainant has the right to be represented by counsel and to make submissions at the hearing. SIRC's senior counsel crossexamines CSIS witnesses when evidence must be heard in secret due to claims of national security confidentiality. ${ }^{80}$

76 RCMP Act, s. 45.35.

77 2003-2004 SIRC Annual Report, online: Security Intelligence Review Committee <http://www. sirc-csars.gc.ca/pdfs/ar_2003-2004-eng.pdf>.

78 Canadian Security Intelligence Service Act, R.S., 1985, c.C-23 [“CSIS Act”].

79 Online: Security Intelligence Review Committee <http://www.sirc-csars.gc.ca/abtprp/indexeng.html>.

80 2006-2007 SIRC Annual Report, online: Security Intelligence Review Committee <http://www. sirc-csars.gc.ca/pdfs/ar_2006-2007-eng.pdf> [2006-2007 Annual Report]. 
Section 54 of the CSIS Act also entitles SIRC to provide the Minister of Public Safety with a special report "on any matter relating to the performance of CSIS' duties and functions" 81 that are of particular importance. In 2006, after the Canadian Civil Liberties Association raised concerns about Mohammed Mansour Jabarah, a Canadian citizen detained in Oman post-9/11, SIRC investigated and submitted a s. 54 report. The approach taken by SIRC in Jabarah's case provides important insight into the efficacy of a complaint to SIRC from an access to justice perspective.

CSIS officials interviewed Jabarah in Oman after being notified by authorities there of his capture. CSIS then arranged for his transportation on a Canadian aircraft to Canada, where he was again interviewed, without the benefit of counsel. According to CSIS, Jabarah confessed to being an al Qaida member and leader of a terrorist cell that planned to bomb the American and Israeli embassies in Singapore and Manila. After 'consultations' with CSIS, Jabarah voluntarily agreed to be transferred to the United States, where he would face terrorism charges. In early 2008, he was convicted of terrorism offences and sentenced to life in prison by a New York federal court. ${ }^{82}$

Despite the then Public Safety Minister's assurances that CSIS's conduct was appropriate and within its mandate, SIRC found that CSIS' actions were not wholly consistent with the CSIS Act and in many ways violated the Charter. ${ }^{83}$ SIRC questioned CSIS' contention that Jabarah's self-crimination and surrender to the U.S. were made freely. In its 2006-2007 Special Report, SIRC criticized CSIS' actions, including the failure to read Jabarah his rights. ${ }^{84}$ SIRC took issue with CSIS' view that, because it is not a police service, it was not required to comply with such Charter protections. SIRC further stated:

\begin{abstract}
Furthermore, an agent of the state must uphold the Charter otherwise Canadian officials would be free to pick and choose to whom certain guaranteed rights and freedoms would apply. Clearly, that would be unacceptable to all Canadians. SIRC recognizes that police and security intelligence agencies in the post 9/11 world must deal with daunting challenges, including globalized and technologically sophisticated terrorist groups. We also know that the relative safety that Canadians enjoy is thanks in large part to the efforts of these same agencies on our behalf. But the obligation to ensure public safety ought not to reduce in any way respect for the rule of law. ${ }^{85}$
\end{abstract}

81 CSIS Act, s. 54.

82 Josh White \& Keith Richburg, “Terror Informant for FBI Allegedly Targeted Agents” Washington Post (19 January 2008) A1, online: The Washington Post <http://www.washingtonpost.com/ wp-dyn/content/article/2008/01/18/AR2008011803766.html>.

83 2006-2007 Annual Report, supra note 80.

84 Ibid.

85 Ibid. In its 2007-2008 Annual Report, SIRC found that CSIS did not properly assess whether an exchange of information with a foreign agency could cause or contribute to the use of torture, as it ought to do pursuant to its obligations domestically under the Charter of Rights and Freedoms, and internationally under various treaties: see SIRC 2007-2008 Annual Report, 
These are robust findings compared to positions taken by the Attorney-General before the Iacobucci Inquiry. In its January 2008 submissions on standards of conduct, the Attorney-General submitted that the Charter does not govern information-sharing or bind Canadian officials acting abroad. ${ }^{86}$

The extent to which the recommendation ${ }^{87}$ that flowed from SIRC's investigation of the Jabarah case have been followed remains doubtful, however. A previous recommendation stemming from a review of CSIS' statements about Human Concern International, a Muslim charitable organization that CSIS has described publicly as linked to al Qaeda, have gone unheeded. SIRC reviewed all of the classified information that CSIS claimed "more than adequately supported" the statement linking the charity to al Qaeda, and found that the allegations were unsubstantiated. ${ }^{88}$ SIRC recommended both an apology and a retraction of the statement to the two national newspapers; to date, CSIS has done neither.

Despite its more robust review powers, SIRC's ability to mete out effective justice is very limited when the Human Concern International and Jabarah cases are considered. In the latter case, the retrospective analysis of Jabarah's treatment at the hands of CSIS agents did not alter the course of his criminal prosecution; whether SIRC's systemic recommendations will be followed remains to be seen, but the failure to secure the release of other detained Canadians, despite SIRC's recommendation that the Department of Foreign Affairs and International Trade [DFAIT] take the lead in matters involving detained Canadians, is cause for some doubt. ${ }^{89}$ Similarly, CSIS' failure to retract its "unsubstantiated statements" about Human Concern International as recommended by SIRC evidences the oversight body's lack of moral and legal suasion vis-à-vis CSIS.

A complaint by Almalki to SIRC would face these same barriers. In addition, there is the antecedent issue of secrecy inherent in CSIS activities: while Almalki knows that he was of interest to CSIS starting in 1998 - ironically, due in part to Almalki's volunteer work with Human Concern International in an irrigation project in Afghanistan - he knows little about the "conduct" of CSIS agents on

online: Security Intelligence Review Committee <http://www.sirc-scars.gc.ca/pdfs/ar_20072008-eng.pdf $>$ at 23-25.

86 Transcript, Hearing on Standards of Conduct (8 January 2008), online: Iacobucci Internal Inquiry <http://www.iacobucciinquiry.ca/pdfs/hearings/2008-01-08-Hearing-on-Standards-ofConduct.pdf $>$ at $42-43$.

87 SIRC made six recommendations stemming from its review, including the updating of a 1987 Memorandum of Understanding between CSIS and DFAIT that would designate the latter as the lead agency in matters involving Canadians detained abroad, and the adoption of a protocol by which CSIS would obtain legal advice from the Department of Justice in any operation which might give rise to the breach of citizen's Charter rights: 2006-2007 Annual Report, supra note 80 .

88 Jim Bronskill, "Watchdog calls for apology from CSIS over unsubstantiated statement about charity" Ottawa Citizen (5 November 2007); 2006-2007 Annual Report, supra note 80.

89 See, for example, the case of Abousfian Abdelrazik, a Canadian detained in Sudan for years, some say at the request of CSIS. Although DFAIT officials claimed Abdelrazik was permitted to return to Canada, he remained precluded from travelling as a result first, of being on the U.S. no-fly list, and then because of DFAIT's requirement that he present a fully paid airline ticket before being issued emergency travel documents. Paul Koring, "CSIS asked Sudan to arrest Canadian, files reveal” The Globe and Mail (5 March 2009) A1. 
which to base a complaint. ${ }^{90}$ Unlike the Human Concern International example, in which a specific public statement is the basis of the SIRC investigation, or Jabarah, where CSIS officials detention and treatment of a suspect are ascertainable to the individual at issue, there is no discrete statement or event that would inform the typical wrongfully accused's decision whether to submit a complaint. Commissioner O'Connor commented on the challenges to effective accountability posed by the lack of transparency inherent in national security investigations, where those affected "will seldom be aware of the specific investigative steps that may have an impact on their interests." ${ }^{11}$

That said, it is possible that the limited disclosure available through the SIRC process might yield modest results. When a complaint is accepted for investigation, the Committee encourages the complainant to do an Access to Information request to CSIS and any relevant departments. Then, when the ex parte portion of the hearing is conducted, the complainant is given a redacted transcript or a summary, prepared by the Committee in consultation with CSIS, which excludes information protected by national security confidentiality. After getting the transcript or summary, the complainant may either pursue issues in cross-examination or (usually more usefully) ask SIRC counsel to pursue the issue in a further ex parte session. ${ }^{92}$

Almalki's ability to test the reliability of intelligence sources, therefore, is theoretically better in the SIRC context than any other, thanks to the role of Senior SIRC Counsel who is responsible for cross-examining CSIS witnesses in camera. Nevertheless, SIRC's mandate is not to provide compensation or a declaration of innocence to a complainant. Even if SIRC found that specific statements by CSIS about Almalki were "unsubstantiated," it is unlikely, given the political context in which CSIS operates and its track record vis-à-vis other SIRC recommendations, that it would issue any public statements of apology.

Commissioner Iacobucci found that the labels attributed to Almalki by intelligence officials - that he was "an imminent threat" and "linked through association to al-Qaeda" - were inaccurate, inflammatory and lacking investigative foundation. ${ }^{93}$ Similar findings have previously been made with respect to descriptors attached to Maher $\mathrm{Arar}^{94}$ and to Human Concern International. ${ }^{95}$ While it is true that the public will rarely know when CSIS 'gets it right,' these examples of CSIS 'getting it wrong' post-9/11 are troubling. About this period of heightened fear of 'the next wave,' Guittet has written that the power of suspicion and the use of intelligence data has been legitimized as reasonable,

90 One of the few examples is described at page 199 of the Iacobucci Report, supra note 7: In late April 2002, CSIS shared information with Malaysian authorities regarding Abdullah that suggested he was an "Islamic extremist." The exact language used and the details of the communication are not described in the Report, presumably on the basis of a national security confidentiality claim.

91 A New Review Mechanism, supra note 74 at 500.

92 Correspondence with SIRC counsel, Gordon Cameron, dated 15 December 2008 [on file with author].

93 Iacobucci Report, supra note 7 at 401.

94 Arar Report, supra note 2 at 13-14.

95 2006-2007 Annual Report, supra note 80. 
though inaccessible, proofs of a person's guilt, leading to condemnation through allegations of terrorism rather than proof. ${ }^{96}$ CSIS plays a critical role in the condemnation of individuals like Almalki, although the SIRC review process is not commensurate with the power that CSIS wields.

\section{COMMISSION OF INQUIRY}

It seems inevitable, in the struggle against terrorism, that mistakes of various kinds will be made.

Commissioner Frank Iacobucci ${ }^{97}$

The limitations of existing institutional vehicles, like SIRC and the CPC, to deal effectively with matters of grave public concern and potential government wrongdoing are often the raison d'etre of public inquiries. ${ }^{98}$ Commissions of inquiry are viewed as a surrogate form of democratic accountability and participation, the effect of which is to restore public confidence and provide a community healing function. ${ }^{99}$

A range of choices presents itself to governments when deciding how to respond to "tragedies such as industrial disasters, plane crashes, unexplained infant deaths, allegations of widespread child sexual abuse, or grave miscarriages of justice." 100 At one end of the spectrum is a full public inquiry pursuant to the federal or provincial inquiries acts. At the other end, "there is the review with no statutory authority, no powers to compel and no hearings." 101 It has been suggested that the latter is appropriate where "there has already been a public trial, there is no suggestion of a wrongful conviction, and there is likely to be little conflict of evidence as to what actually happened." 102 It has also been posited that since the federal Inquiries Act nowhere requires that an inquiry be held in public, if the information needed can be gathered without public hearings, "this may be the best way to safeguard reputations" of those whose misconduct is at issue. ${ }^{103}$

All or some of these considerations may have played a role in the establishment of the inquiry over which former Supreme Court Justice Frank Iacobucci presided. The Iacobucci Inquiry found its genesis in the Arar Report, in which Commissioner O'Connor called for an independent review of the cases of Al-

96 Guittet, supra note 56 at 5-6.

97 Iacobucci Report, supra note 7, Commissioner's Statement at 5.

98 Archie Campbell, "The Bernardo Investigation Review” in Allan Manson, ed., Commissions of Inquiry: Praise or Reappraise? (Toronto: Irwin Law, 2003) 381 at 389.

99 A. Manson \& D. Mullan, "Lessons from Walkerton" in Manson, ibid. 499 at 512-513. See also Phillips v. Nova Scotia (Commission of Inquiry into the Westray Mine Tragedy), [1995] 2 S.C.R. 97 [Phillips].

100 Phillips, ibid.

101 Campbell, supra note 98 at 390. For this type of review, see British Columbia, Report of Inquiry: Jericho Hill School (Vancouver: the Commission, 1974) which, according to its special counsel, was an informal investigation primarily out of respect for victims of abuse who did not want to relive their trauma in public; see Thomas Berger, Canadian Commissions of Inquiry: An Insider's Perspective" in Manson, supra note 98 at 26.

102 Campbell, supra note 98 at 390.

103 Ann Chaplin, "Commentary" in Manson, supra note 98 at 468. 
malki, El Maati and Nureddin. ${ }^{104}$ Commissioner O'Connor's recommendation stemmed, at least in part, from the long campaign by several non-governmental groups, including Amnesty International and the British Columbia Civil Liberties Association, which called for an inquiry into the perceived pattern of complicity in torture represented by the cases of Arar and the other three men. Commissioner O'Connor's recommendation, however, was worded in a way that would come to justify very unusual terms of reference: while he called for a comprehensive inquiry that would inspire public confidence in the outcome, he suggested that something other than a "full-scale public Inquiry" would be desirable since national security issues were involved. ${ }^{105}$

Soon thereafter, counsel for the three men wrote to the Minister of Public Safety asking that the inquiry process be designed independently. ${ }^{106}$ In particular, they expressed concern that Department of Justice lawyers were drafting the terms of reference for the Inquiry. Since Commissioner O'Connor had found that "DOJ lawyers and the Project A-O Canada team maintained open lines of communication" throughout the investigation of the three men; that "Project A-O Canada personnel sought legal advice for all investigative steps," and that DOJ lawyers "regularly attended the investigators' meetings and joint management team meetings where the information sharing was discussed," 107 an appearance of a conflict of interest, if not an actual conflict, ought to have precluded Justice lawyers from drafting the terms of reference. Counsel called instead for an independent third party, like Commissioner O'Connor or his counsel, to be consulted by government in the design of the review process. ${ }^{108}$

The requests by lawyers for the men were unsuccessful, but emblematic of a larger irony true of almost all commissions of inquiry. The very entity whose officials are to be the subject of the review decides whether and how to establish the review process. Some have described this fact as a "truly extraordinary" feature of our democracy, since "very few nations subject their governments to this kind of independent and public scrutiny." 109 Others submit that the dependence on Cabinet's will to call an inquiry "seriously hamper[s] the capacity of the commission of inquiry to serve as an effective instrument for the formulation of

104 Arar Report, supra note 2 at 278.

105 Ibid.

106 Letters dated October 11 and 17, 2006 from J. Kalajdzic to Stockwell Day [on file with author].

107 Arar Report, Factual Background, Vol. 1 at 50.

108 Note that many legal scholars have similarly called for alternatives to the sole discretion currently reposed in Cabinet for the constitution of inquiries: see Bryan Schwartz, "Public Inquiries" in Manson, supra note 98, 443 at 448 [recommending giving a body other than the government of the day the formal authority to define the mandate of the inquiry and appoint its commissioner]; David P. Shugarman, "Commentary" in Manson, supra note 98, 127 at 140-141 [recommending widening the mandate of the Auditor-General]; Roderick Macdonald, "Interrogating Inquiries" in Manson, supra note 95, 473 at 487-488 [recommending Standing Committee of Parliament be charged with role]; and Robert Centa \& Patrick Macklem, infra note 110 [recommending the Law Commission of Canada act as permanent base for federal inquiries].

109 Justice John H. Gomery, "The Pros and Cons of Commissions of Inquiry” (2006) 51 McGill L.J. 783 at para. 11. 
public policy" and enables governments, "for purely partisan reasons, to refuse to establish commissions of inquiry into matters that clearly merit independent investigation." 110

The Federal Cabinet ultimately decided to call an "internal inquiry" into the actions of Canadian officials in relation to Almalki, El Maati and Nureddin. ${ }^{111}$ The preamble to the terms of reference recalled Commissioner O'Connor's caveat about full-scale public inquiries and directed the Commissioner to "adopt any procedures and methods that he considers expedient for the proper conduct of the Inquiry, while taking all steps necessary to ensure that the Inquiry is conducted in private." 112 Following an initial hearing to determine standing, ${ }^{113}$ counsel for the three men and for several intervenors submitted that "private" did not mean ex parte, that the terms only called for in camera hearings where national security confidentiality claims were made, and that counsel should be security cleared to permit their attendance at, and participation, in the private hearings. ${ }^{114}$ To do otherwise would place expedition above transparency and thoroughness, and would reward the government for overclaiming national security confidentiality during the Arar Inquiry. ${ }^{115}$ Commissioner Iacobucci rejected this interpretation of the terms of reference, and adopted instead the view proposed by the Attorney-General: for reasons of national security confidentiality and expedition, "private" must be interpreted to mean in camera and ex parte. ${ }^{116}$ Thus, none of the Inquiry's hearings were held in public, save for one-and-a-half days of public submissions on the legal standards for assessing conduct of officials. ${ }^{117}$ No documentary evidence was disclosed to non-government participants in the Inquiry; no opportunity to test the evidence given by witnesses was provided; and no transcripts were made available. A "draft factual narrative" which contained a summary of the evidence heard by Commission counsel that was not subject to national security confidentiality was provided to counsel for the three men and intervenors, but not to the three men themselves. ${ }^{118}$

110 Robert Centa \& Patrick Macklem, “Securing Accountability Through Commissions of Inquiry: A Role for the Law Commission of Canada" (2001) 39 Osgoode Hall L.J. 117 at para. 47. Similar concerns were more recently expressed about the discretion vested in the Executive in relation to inquiries. Democracy Watch sought unsuccessfully to compel the Ethics Commissioner to investigate the propriety of the Prime Minister drafting the terms of reference for an inquiry into the Mulroney-Schreiber affair, stating that in light of the conflicts of interest, an independent authority, such as the federal director of public prosecutions, ought to decide the terms of any inquiry. See Jim Brown, "Court won't hear claim Harper broke ethics law" (21 January 2009) The Globe and Mail, online: The Globe and Mail <http://www.theglobeandmail.com/servlet/ story/RTGAM.20090121.wPOLmulroney0121/BNStory/International/>.

111 Order in Council, P.C. 2006-1526, Amendment P.C. 2008-31, Amendment P.C. 2008-1489.

112 Arar Report, supra note 2 at 278.

113 Ruling on Participation and Funding dated 2 April 2007, Iacobucci Report, supra note 7, Appendix B.

114 Ruling on Terms of Reference, 31 May 2007, Iacobucci Report, supra note 7, Appendix C at 8.

115 Arar Report, supra note 2 at 301-304.

116 Ruling on Terms of Reference, supra note 114 at 6, 20-22.

117 Held January 8 and 9, 2008; see amended notice of hearing on standards of conduct, Iacobucci Report, supra note 7, appendix I.

118 Ruling on Application made by Notice of Application dated September 26, 2008, Iacobucci Report, supra note 7 , appendix K. 
This secretiveness was highly unusual for commissions of inquiry. Of the more than 400 inquiries called pursuant to inquiries legislation since Confederation, ${ }^{119}$ six had terms of reference noting the necessity of protecting information relating to national security: the Royal Commission on Espionage, ${ }^{120}$ the McDonald Commission, ${ }^{121}$ Somalia, ${ }^{122}$ Arar, ${ }^{123}$ and Air India Flight $182 .{ }^{124}$ Of the six, only the Espionage Commission, which was resoundingly condemned for its secrecy and abuse of civil liberties, ${ }^{125}$ and the Iacobucci Inquiry had presumptively private mandates, even though all six inquiries of necessity involved evidence against which the government claimed national security confidentiality. Indeed, the McDonald Commission, which investigated the actions of RCMP officials, was directed by its terms of reference "to hold in camera all matters relating to national security and in all other matters where the Commissioners [deemed] it desirable in the public interest or in the interest of the privacy of individuals involved in specific cases which may be examined." 126 The Commissioners rejected the inference that there would be little evidence heard in public given the nature of the Inquiry, stating that it "is of the greatest importance that hearings before a Tribunal of Inquiry - which is what they call them in England - should be held in public. It is only when the public is present that the public will have complete confidence that everything possible has been done for the purpose of arriving at the truth. ..."127

119 Gomery, supra note 109 at para. 10 .

120 Report of the Royal Commission appointed under Order of Council P.C. 411 of February 5, 1946 to Investigate the Facts Relating to and the Circumstances Surrounding the Communication by Public Officials and Other Persons in Positions of Trust of Secret and Confidential Information to a Foreign Power (Ottawa: E. Cloutier, printer to the King, 1946).

121 Commission of Inquiry Concerning Certain Activities of the Royal Canadian Mounted Police, Second Report (23 January 1981), online: Library and Archives Canada <http://epe.lac-bac. gc.ca/100/200/301/pco-bcp/commissions-ef/mcdonald1979-81-eng/mcdonald1979-81report2/mcdonald1979-81-report2-vol2-eng/mcdonald1979-81-report2-vol2-part4-eng.pdf>.

122 Commission of Inquiry into the Deployment of Canadian Forces to Somalia (20 March 1995).

123 Commission of Inquiry into the Actions of Canadian Officials in Relation to Maher Arar (5 February 2004).

124 Commission of Inquiry into the Investigation of the Bombing of Air India Flight 182 (1 May, 2006).

125 See e.g. Allan Manson, "The Rule of Law and Academic Freedom in Fearful Times: Canada after Gouzenko" in James L. Turk \& Allan Manson, eds., Free Speech in Fearful Times (Toronto: James Lorimer \& Co., 2007) at 63-84; Dominique Clement, "Spies, Lies and a Commission: A Case Study in the Mobilization of the Canadian Civil Liberties Movement" (2001) 7 Left History at 53-79, online: Canadian Intelligence Resource Centre <http://circ.jmellon.com/docs/view. asp?id=865>. "The Royal Commission on Espionage epitomized everything democracies fear of governments with too much power. The commission overrode a police investigation and generally acted like an independent judicial system by ignoring traditional liberties including the right to engage counsel, to know one's charges, and a host of others" (at 78).

126 Order in Council, P.C. 1977-1911 dated 6July 1977 at para. 2, online: Library and Archives Canada <http://epe.lac-bac.gc.ca/100/200/301/pco-bcp/commissions-ef/mcdonald1979-81-eng/mcdonald1979-81-report2/mcdonald1979-81-report2-vol2-eng/mcdonald1979-81-report2vol2-part4-eng.pdf>.

127 Commission of Inquiry Concerning Certain Activities of the Royal Canadian Mounted Police, Second Report (23 January 1981), supra note 121 at 1159-1160. 
Repeated applications by counsel for the men and other non-government participants to open up the Iacobucci process in order to inspire public confidence in, and bring greater transparency, to the Inquiry's work were rejected largely on the basis of a restrictive interpretation of the terms of reference. ${ }^{128}$ This, despite the Prime Minister's statements that amendments to the Inquiry's mandate to expressly require public hearings were unnecessary because "Justice Iacobucci has all the power necessary to decide whether something should be held in private or whether it can be held in public." 129

That no redacted evidence was disclosed to the parties is also a sign of the normalization of extraordinary measures discussed by Gross and others. ${ }^{130}$ That is, extraordinary measures taken within traditional legal systems start us down a slippery slope on which what was formerly "extraordinary" becomes the new norm, and what was necessary in the name of anti-terrorism measures becomes acceptable in other areas. No empirical study has been conducted regarding the incidence of national security claims post-9/11 in Canada, be it in the immigration, criminal or privacy legislation contexts. National security claims have had a markedly increased presence, however, within public inquiries. Apart from the government's overclaiming in the Arar context as referred to earlier, the government's unprincipled approach to national security claims almost brought the Air India Inquiry to a halt ${ }^{131}$ and was the subject of commentary at the Federal Court. ${ }^{132}$ The culture of secrecy and resistance to public scrutiny that has been observed generally in the national security sphere, ${ }^{133}$ has creeped into public inquiries as well. Pointedly, in respect of the Arar, Air India, and Iacobucci Inquiries, one RCMP official (with the concurrence of CSIS' top brass) referred to them, with no small irony, as "judicial jihad." 134

128 See Rulings dated 6 November 2007, 23 May 2008, 22 July 2008 and 8 October 2008, online: Iacobucci Internal Inquiry <http://www.iacobucciinquiry.ca/en/rulings/index.htm>.

129 Andrew Duffy, "PM won't force disclosure rules on inquiry; Judge has authority to decide what's secret: Harper" Ottawa Citizen (13 October 2007) A5.

130 Oren Gross, "Chaos and Rules: Should Responses to Violent Crises Always be Constitutional?" (2003) 112 Yale L.J. 1011 at 1021-1022. See also Lawyers' Committee for Human Rights, Assessing the New Normal: Liberty and Security for the Post-September 11 United States (Septempter 2003), online Human Rights First <http:/www.humanrightsfirst.org/us_law/loss/ assessing/assessingnewnormal.htm>.

131 Jim Bronskill, "Judge threatens to suspend Air India Inquiry" Canadian Press (19 February 2007) ["Former Supreme Court of Canada Justice John Major said Monday that he will give lawyers two weeks to reassess their claims that national security would be endangered by fuller disclosure of documents and public hearings on many issues. ... [H] e will adjourn the hearings until at least March 5, saying he hopes the government will come around to share his view by that date."].

132 R. v. Khawaja, 2007 F.C. 463, aff'd 2007 FCA 388; Canada (A.G) v. Canada (Commission of Inquiry into the Actions of Canadian Officials in Relation to Maher Arar), [2007] F.C.J. No. 1081.

133 See e.g. Kent Roach, "Must We Trade Rights for Security? The Choice between Smart, Harsh, or Proportionate Security Strategies in Canada and Britain” (2006) 27 Cardozo L. Rev. 2151 at 2167.

134 Sheppard, supra note 34 at A1. ["An RCMP email disclosed in a Toronto extradition hearing earlier this month called the trio of inquiries 'judicial jihad.' (CSIS Deputy Director) Hooper likes that phrase."]. 
Commissioner Iacobucci submitted his report on October 20, 2008, and the government released the public version a day later. The Commissioner made the following key findings:

- He was unable to determine on the record available to him whether the actions of Canadian officials "likely contributed to" and therefore "resulted indirectly in" Almalki's detention in Syria.

- Almalki suffered mistreatment in Syria amounting to torture.

- Almalki's mistreatment resulted "indirectly" from the sharing of the RCMP's Supertext database and the sending of questions to Syria.

- Consular officials were deficient in their provision of services. ${ }^{135}$

The Commissioner did not, however, name the individuals whose conduct caused the miscarriage of justice. Similarly, he did not expressly clear Almalki's name in the way that Commissioner O'Connor had done for Arar. Citing his terms of reference, Commissioner Iacobucci wrote:

Following on the observation that the Inquiry was investigative and not adversarial, I cannot emphasize enough that the subject matter of the Inquiry was the actions of Canadian officials, not the conduct of Mr. Amalki [sic], Mr. Elmaati and Mr. Nureddin. They are not charged with anything, are not on trial, and have no case to meet. They have certainly not been convicted of any crime.

In setting out the factual background to my findings, I have necessarily made references to certain allegations about these three individuals. However, nothing I state in this report should be taken as an indication that those allegations are founded. Making determinations concerning these allegations is plainly and simply not within my Terms of Reference.

I recognize that the mere fact of being named in allegations, especially allegations that are repeated publicly, can affect the reputations of those named and their families. That is regrettable, but unfortunately, largely unavoidable in view of the matters that I have been mandated to examine. But I reiterate that Mr. Amalki [sic], Mr. Elmaati and Mr. Nureddin are not charged with and have not been convicted of any offence. Both the law and fundamental fairness dictate that they be presumed innocent of any wrongdoing. ${ }^{136}$

Despite the clarity of this language in the introductory chapter, the difference in

135 Iacobucci Report, supra note 7 at 37-38.

136 Ibid. at $43-44$. 
approach by the two Commissioners - and the lack of clearly exculpatory language in the Iacobucci Report - was not lost on the press, ${ }^{137}$ and questions were raised as to whether Almalki's name was truly vindicated.

The limited terms of reference and the insistence on holding the Inquiry virtually entirely in secret have ramifications in our access to justice framework. From a process perspective, the Iacobucci Inquiry was a failure for Almalki and the other two men. ${ }^{138}$ The non-government organizations with standing at the Inquiry were unanimous in their view that the process was so unacceptable that it should never be repeated, no matter what the content of the ensuing report. ${ }^{139}$ The process was said to be dehumanizing and disempowering for the men, and ultimately undermined their ability to be confident in the accuracy and thoroughness of the final report. ${ }^{140}$ In this way, the oft-cited "naming and blaming" function of the public inquiry process for victims and survivors of tragedies was lost. ${ }^{141}$

From a substantive justice perspective, the Inquiry yielded important results, in the form of answers to some of Almalki's questions about his ordeal, and an unequivocal recognition that his mistreatment amounted to torture. For a torture survivor, the latter has particular importance. Although Almalki could also rightly feel some vindication from the assessment by Commissioner Iacobucci that at least in two instances, the terrorist label was misapplied to Almalki, he claimed that the Inquiry experience was in many ways a recurrence of his experience in Syria, where he was powerless to defend himself against the words and actions of his accusers. ${ }^{142}$ Moreover, the repetition in the report of untested but hugely damaging accusations of terrorism may serve to confirm condemnation by suspicion for some.

Inquiries also generally aspire to be "very useful tools for reminding leaders and the public of the importance of the democratic obligations to provide an accounting - answers - for what those entrusted with power do with it." ${ }^{43}$ The lack of public engagement in the Iacobucci Inquiry process equally has negative ramifications for the social symbolism aspect of access to justice. As with any

137 See e.g. Jim Brown, “Apology, Compensation Still at Issue in Terror Cases” (23 October 2008) HamiltonSpectator, online:HamiltonSpectator<http://www.thespec.com/printArticle/453732>; and "Canadian 'Role in Syria Torture" The British Broadcasting Corporation (21 October 2008), online: BBC News <http://news.bbc.co.uk/2/hi/americas/7683187.stm>.

138 Jasminka Kalajdzic, "Outside the Internal Inquiry: The Nature and Impact of Secrecy at the Iacobucci Inquiry" (draft on file with author). It was also a failure to at least some public commentators; see "Leeway for Mr. Iacobucci," Editorial, Globe and Mail (14 August 2007) and Thomas Walkom, "Secrecy Threatens Credibility of Iacobucci Inquiry" The Toronto Star (18 October 2007).

139 Backgrounder, "The Internal Inquiry Process: Fostering a Culture of Impunity" (17 October 2008), online: Kerry Pither <http://kerrypither.com/wp-content/uploads/2008/10/ iacobucciprocess 2.pdf $>$. In addition, one intervenor organization, the B.C. Civil Liberties Association, pulled out of the Inquiry in early 2008 due to the overly secretive process.

140 Ibid.

141 Macdonald, supra note 108 at 482.

142 Amnesty International, Final Submissions at paras. 25-28, online: Iacobucci Internal Inquiry <http://www.iacobucciinquiry.ca/pdfs/documents/2008-06-21-Amnesty-InternationalFINAL-en.pdf>.

143 Shugarman, "Commentary," supra 98 at 130. 
inquiry, 'success' can only fully be measured by the government's response to the commissioner's findings. The Minister for Public Safety was quick to dismiss the pattern of human rights abuses in national security investigations as "good people acting with deficient procedures," on the heels of Commissioner Iacobucci's statement that he found no evidence that Canadian officials acted maliciously. ${ }^{144}$ In such statements, we hear echoes of the attempts often made to dismiss wrongful convictions as systemic problems in the administration of justice. ${ }^{145}$ In doing so, we lose opportunities to identify individual behaviour within such institutions that leads to miscarriages of justice. The reluctance of Commissioner Iacobucci to identify the individuals who were responsible for what occurred in Almalki's case compromises the accountability function of the inquiry model, and fails to secure meaningful justice for the victim.

\section{TORT CLAIM}

The nexus between commissions of inquiry and civil litigation has been the subject of both general observation and specific comment at one of the few public hearings before the Iacobucci Inquiry. Fact-finding inquiries in particular can be reframed as an accessory to litigation, "souped-up police investigations" or "state-sponsored 'pre-trial' discovery processes." 146 Similarly, counsel for the Attorney-General submitted to Commissioner Iacobucci that the Inquiry could not be used by Almalki and the other men to further their litigation interests:

They have a substantial and direct interest in the subject matter of this inquiry, as you have found. That is the nature of their interest. It is an interest in the subject matter of this inquiry. They do not have a legal interest. They undoubtedly have other interests beyond the Terms of Reference here, including significant litigation claims that may be pursued. Internal inquiries should not become a proxy for those other interests. [Emphasis added]

They also have stated an interest in using this inquiry as a vehicle to clear their names. This is not that vehicle. It is not an inquiry into their actions. To make it an inquiry that would look to the prospect of clearing their names is equally to make it an inquiry that has the prospect of condemning these individuals. And that is not the case. That is not the task of this inquiry. ${ }^{147}$

144 Haroon Siddiqui, "Disturbing complicity on torture” The Toronto Star (23 October 2008).

145 Kent Roach, "Inquiring Into the Causes of Wrongful Convictions" (1999) 35 Criminal Law Bulletin 152 at 168 .

146 Macdonald, supra note 108 at 478.

147 Transcript, Hearings on Terms of Reference and Procedure (17 April 2007) at 68-69, online Iacobucci Inquiry <http://www.iacobucciinquiry.ca/pdfs/hearings/2007-04-17_original-transcript-en.pdf $>$ [emphasis added]. 
Despite the Attorney-General's attempt to separate the civil litigation implications from the Inquiry process, the terms of reference betray the government's conscious effort to insulate its officials from potential civil liability. As previously described, the terms create the presumption of secrecy when they call for the Commissioner to take "all steps necessary to ensure that the Inquiry is conducted in private." The terms also specifically mandate that the Commissioner only examine actions of Canadian officials insofar as they are causally connected to either detention or mistreatment, ${ }^{148}$ a product of the Attorney-General's experience in the Arar Inquiry, where Commissioner O'Connor construed his mandate to include reporting on actions not only that "caused or contributed" to Arar's fate, but that also created or increased an unacceptable risk of harm. ${ }^{149}$ Commissioner Iacobucci took a somewhat more limited approach, although one that was more expansive than the "but for" test advocated by the AttorneyGeneral, when he concluded that his mandate permitted him to make findings where, based on all of the evidence and the rational inferences to be drawn from it, the actions of Canadian officials could be said to have "likely contributed" to the detention and mistreatment of the three men. ${ }^{150}$ Interestingly, it was precisely because his mandate did not permit him to draw any conclusions about civil or criminal liability that he found the "but for" standard used in tort law to be inappropriate. ${ }^{151}$

Commissioner Iacobucci ultimately found certain actions by DFAIT and the RCMP to be "deficient," as he interpreted that word in the terms of reference. ${ }^{152}$ He was careful to point out that he found no malice on the part of the officials in question, and that the deficient actions led "indirectly" to detention and mistreatment. By virtue of the Supreme Court of Canada's decision in the Krever Commission case, ${ }^{153}$ however, none of these findings are binding in the outstanding civil proceedings brought by Almalki against the Attorney-General and several individuals. ${ }^{154}$ That the work of public inquiries cannot be utilized in subsequent civil trials has led Trebilcock and Austin to suggest that it would be "better to resolve victims' rights to compensation through generic administrative no-fault compensation schemes rather than the civil litigation process." ${ }^{155}$ Still, findings

148 Terms of Reference, supra note 114 at para. A(i).

149 Arar Report, supra note 2 at 288.

150 Iacobucci Report, supra note 7 at 343 .

$151 \mathrm{Ibid}$. at 341 .

$152 \mathrm{Ibid}$. at 343 . He found that the term "deficiency" should be given its ordinary meaning of conduct falling short of a norm, be it a standard that existed at the time of the conduct, the absence of a standard when there ought to have been one, or acting in accordance with a standard that was itself deficient.

153 Canada (A.G.) v. Canada (Commission of Inquiry on the Blood System in Canada - Krever Commission), [1977] S.C.J. No. 83 at para. 23.

154 Fresh Statement of Claim, Almalki et al. v. Attorney-General (Canada), Michel Cabana, Warren Coons, Steve Covey, Brian Davis, Ward Elcock, Dennis Fiorido, Richard Flewelling, Scott Heatherington, William John Hooper, Leo Martel, Franco Pillarella, Randy Walsh and Giuliano Zaccardelli, Court file no. 06-CV-035416 [on file with author].

155 Michael Trebilcock \& Lisa Austin, "The Limits of the Full Court Press: Of Blood and Mergers" (1998) 48 U.T.L.J. 1 at 53. See also Kaiser, supra note 29 at 143-146 (suggesting that an Imprisonment Compensation Board be created both to investigate claims of wrongful conviction and determine eligibility for and quantum of compensation). 
of commissions of inquiry can and often do influence mediation processes within the civil action. Arar's multi-million dollar compensation resulted from an intense mediation process within just a few months of the release of Commissioner O'Connor's report. The findings in the Iacobucci Report also might signal the ease - or difficulty - with which Almalki and the other men will be able to establish that the investigations were negligent and caused, among other things, false imprisonment, battery, defamation, and breach of Charter rights. ${ }^{156}$

There are two fundamental limitations in using tort law and civil litigation to achieve the ends sought by the wrongfully accused. First, as Archibald Kaiser argued twenty years ago in relation to the "compensatory obstacles" faced by the wrongfully convicted, there are inherent difficulties in using tort law to mediate claims between the individual and the state. ${ }^{157}$ These difficulties are both structural and normative; that is, civil litigation is expensive and uncertain by nature, and the relevant causes of action are either nascent (such as the tort of negligent investigation) or notoriously difficult to establish (such as malicious prosecution). A second overarching impediment presented by a tort action is the particular role national security privilege will play in any such action, whatever the nominate torts claimed.

No action brought by a wrongfully accused person in the national security context has gone to trial in Canada. Experience with such litigation south of the border, and the accompanying academic and legal debates, provide insight as to the potential limitations of civil litigation as an access to justice mechanism. On October 9, 2007, the U.S. Supreme Court denied the petition of Khaled ElMasri, a German citizen of Lebanese descent, who sought damages for violation of the Due Process Clause and various international human rights instruments stemming from his extra-ordinary rendition and torture by CIA agents. ${ }^{158}$ The CIA's targeting of El-Masri was reported to have been acknowledged by senior White House officials as an "error" resulting from mistaken identity, ${ }^{159}$ in a rendition program that the U.S. President himself acknowledged publicly. Nevertheless, the federal government asked the court to dismiss the case on grounds that the proceedings would jeopardize national security and reveal state secrets. The Fourth Circuit Court of Appeals agreed that the state secrets privilege properly applied and struck the claim. ${ }^{160}$

The state secrets privilege is a common law evidentiary privilege in the

156 Syrian officials are not named defendants. As a result of Canada's State Immunity Act, R.S.C. 1985, c.S-18 and a line of authorities, including Bouzari v. Iran, [2002] O.J. No. 1624 (Sup. Ct. J.), aff'd [2004] O.J. No. 2800 (C.A.), Almalki is unable to sue Syrian officials directly in Canada. For various discussions of tort claims for torture against foreign regimes, see Noah B. Novogrodsky, "Immunity for Torture: Lessons from Bouzari v. Iran" (2007) 18 E.J.I.L. 939; John Terry, "Taking Filartiga on the Road: Why Courts Outside the United States Should Accept Jurisdiction Over Actions Involving Torture Committed Abroad” in Craig Scott, ed., Torture as Tort (Portland: Hart Publishing, 2001) 191; and Craig Forcese, "De-Immunizing Torture: Reconciling Human Rights and State Immunity” (2007) McGill L.J. 127.

157 Kaiser, supra note 29 at 112-117.

158 Several court documents are available on the American Civil Liberties Union website, online: American Civil Liberties Union <http://www.acluva.org/docket/elmasri.html>.

159 Dana Priest, "Wrongful Imprisonment: Anatomy of a CIA Mistake. The Washington Post (December 4, 2005).

160 El-Masri v. Tenet, 479 F. 3d 296 (4th Cir. 2007). 
United States. Its purpose is to block the disclosure in litigation of information that will damage national security. The privilege is derived from the President's constitutional authority over military and diplomatic affairs, and must be formally asserted by the head of the Executive Branch agency with control over the state secrets in question. ${ }^{161}$ In the El-Masri case, the Director of the CIA filed an ex parte declaration, as well as an unclassified version, stating that damage to national security could result if the defendants were required to admit or deny El-Masri's allegations. ${ }^{162}$ The District Court found that the privilege was validly asserted, and then went on to consider whether special procedural mechanisms could be devised to prevent the disclosure of the state secrets if the case were allowed to proceed. Where the very question on which a case turns is itself a state secret - here, the existence and operation of America's extra-ordinary rendition program - dismissal was said to be the appropriate remedy. ${ }^{163}$ The court held that because the entire aim of the suit was to prove the existence of state secrets, procedures like security clearing counsel would be inadequate as they would entail considerable risk of inadvertent disclosure. In the result, El-Masri's private interests gave way to national interests in preserving state secrets.

In his closing words, Judge Ellis of the District Court commented on the apparent unfairness of his decision, stating that

"all fair-minded people, including those who believe that state secrets must be protected, that this lawsuit cannot proceed, and that renditions are a necessary step to take in this war, must also agree that El-Masri has suffered injuries as a result of our country's mistake and deserves a remedy. Yet, it is also clear from the result reached here that the only sources of that remedy must be the Executive Branch or the Legislative Branch, not the Judicial Branch." 164

Commentators universally decried the result in El-Masri and the state secrets privilege as emblematic of broader patterns of secrecy and the lawless enclave in which national security claims reside. ${ }^{165}$ The critiques also pointed out that the asserted dangers to national security were often subsequently demonstrated to have been exaggerated; " $[\mathrm{t}] \mathrm{o}$ put it another way, when national security claims are advanced, there may well be a confusion of the interests of the administration

161 El-Masri v. Tenet, 437 F. Supp. 2d 530, 536 (E.D. Va. 2006) at 536.

162 Ibid. at 537.

$163 \mathrm{Ibid}$. at 539. See also United States v. Reynolds, 345 U.S. 1 (1953) and Sterling v. Tenet, 416 F.3d 338, 347-348 (4th Cir. 2005).

164 Ibid. at 541 .

165 J. Hafetz, "Secret Evidence and the Courts in the Age of National Security: Habeus Corpus, Judicial Review, and Limits on Secrecy in Detentions at Guantanamo" (2006) 5 Cardozo Pub. L. Pol'cy \& Ethics J. 127 at 127-128. See also J. Steven Gardner, "The State Secret Privilege Invoked in Civil Litigation: A Proposal for Statutory Relief” (1994) 29 Wake Forest L. Rev. 567; and Amanda Frost, "The State Secrets Privilege and Separation of Powers" (2007) 75 Fordham L. Rev. 1931. 
in power with the interest of the nation." 166 In keeping with Judge Ellis' view that cases involving state secrets were not proper grist for the judicial mill, several legal commentators have offered recommendations for alternative approaches, including a statutory amendment that would compensate people whose claims cannot go forward due to state secrecy, ${ }^{167}$ or by forcing the government to choose between permitting the suit to go forward or else have judgment rendered for the plaintiff. ${ }^{168}$

Canada's version of the state secrets privilege can be found in s. 38 of the Canada Evidence Act, which prevents the disclosure of "potentially injurious information" and "sensitive information" in an otherwise open courtroom. ${ }^{169}$ Classification of information as "potentially injurious" need not be made by the head of the Executive body with control of the classified information; rather, "every participant" or "official" who, in connection with a proceeding, expects to disclose information that the participant or official believes is potentially injurious, must give notice to the Attorney-General before introducing the evidence, and where the Attorney-General objects, the matter is taken up by the Federal Court. Importantly, the civil trial judge tasked with determining whether Almalki has made out his causes of action, would not have access to the secret evidence since it is the Federal Court judge, not the trial judge, who adjudicates the privilege issue. Moreover, although not yet invoked, a new provision in the Canada Evidence Act enacted after 9/11 gives the Attorney-General power to issue a certificate to block a court order of disclosure. ${ }^{170}$

The impact of s. 38 on the ability of a plaintiff to establish a claim in tort by preventing disclosure of relevant evidence does not turn on the nature of the tort action - with one possible exception. Unlike negligence, false imprisonment or battery, a defamation claim potentially creates presumptions of liability that the defendant would have to defeat. Almalki, for example, could rather easily establish that the labels of "Islamic extremist" and "Bin Laden associate" attributed to him by the RCMP were defamatory. The Crown would then have to assert an affirmative defence - such as truth or justification - or invoke an absolute privilege, like that afforded to high officials. ${ }^{171}$ In the case of the truth defense,

166 Thomas I. Emerson, "National Security and Civil Liberties" in The First Amendment and National Security 84-85 (1984), reprinted in Congressional Research Service Report for Congress, Protecting Classified Information: A Compilation and Index of Major Findings and Recommendations, 1985-1987.

167 Gardner, supra note 165 at 601-606.

168 Robert Chesney, "State Secrets and the Limits of National Security Litigation" (2007) 75 Geo. Wash. L. Rev. 1249 at 1312-1313; Louis Fisher, In the Name of National Security: Unchecked Presidential Power and the Reynolds Case (Kansas: University of Kansas Press, 2006).

169 R.S. 1985 , c.C-5, ss. 38.01 and 38.02.

170 Ibid. at s. 38.13. See Kent Roach, "The Role and Capacities of Courts and Legislatures in Reviewing Canada's Anti-terrorism Law” (2008) 24 W.R.L.S.I. 5.

171 The privilege extends to statements made by high executive officers acting in the course of their official duties relating to matters of state. It is beyond the scope of this paper to consider the strengths of such a privilege claim, but it is worth noting that here, too, s. 38 may work against the plaintiff since the government may be able to successfully prove a "high" official authorized publication of the defamatory statement and therefore establish the immunity, without producing all relevant information. See Raymond E. Brown, The Law of Defamation 
the onus rests on the Crown to produce evidence which would satisfy the judge that the labels and the particular conduct charged in the publication were true. It is not for Almalki to establish an utterance is false; the law presumes that every defamatory statement is false. ${ }^{172}$ The Crown, therefore, would be forced to make a choice between revealing the information or invoking the national security privilege and risk failing to prove its truth defence.

Whether the operation of s. 38 will significantly frustrate the ability of a tort litigant like Almalki to successfully prosecute an action in the national security context remains to be seen. ${ }^{173}$ Section 38.14 of the Canada Evidence Act protects the accused in criminal matters in the event non-disclosure of secret evidence frustrates his or her right to a fair trial. Importantly, the provision does not apply in the civil litigation context. Moreover, the government's track record in overclaiming national security confidentiality justifies speculation that the AttorneyGeneral might be willing to subordinate the personal interests of the plaintiff to the collective interest in national security by claiming national security confidentiality over significant portions of the evidence relevant to establishing the causes of action. ${ }^{174}$ Even if the government is willing to withdraw a prosecution in order to protect secrets in the criminal context, as has been suggested elsewhere, ${ }^{175}$ the same rationale would not necessarily apply in the civil context where the government is a named defendant and has many incentives to resist liability. At the very least, a battle over what ought to be produced in discovery will be involved and protracted, requiring adjudication by the Federal Court. The information disclosed in the Iacobucci Report about Canadian officials' conduct in relation to Almalki will provide guidance as to what can fairly be considered unclassified information, and in this way, Almalki is not as distinctly disadvantaged as other wrongfully accused national security targets. ${ }^{176}$ Nevertheless, he must satisfy a higher standard of causation than that used by Commissioner Iacobucci in order to establish negligence, his primary cause of action. ${ }^{177}$ In any event, a successful claim that negligent conduct led to Almalki's mistreatment in Syria does not equate to exoneration, for it could be seen as only confirming that the prohibi-

in Canada, vol. II, 2d ed. (Scarborough: Carswell, 1999) at \$12.2(4) where he states that an official may be protected against actions for defamatory publications "if the communication is one which courts will refuse to require that it be produced."

172 Ibid. at $\$ 10.2$.

173 For a detailed comparison of s. 38 and the state secrets privilege, see J. Kalajdzic, "Litigating State Secrets": A comparitive Study of National Security Privilege in Canadian, U.S. And British Civil Cases" (2010) Ottawa L. Rev. [forthcoming].

174 A similar calculus operates in the state secret jurisprudence: "When the state secrets privilege is validly asserted, the result is unfairness to individual litigants - through the loss of important evidence or dismissal of a case - in order to protect a greater public value" [Fitzgerald v. Penthouse Int'l Ltd., 776 F.2d 1236 (4th Cir. 1985)].

175 Roach, supra note 170 .

176 Benamar Benatta, for example, a Canadian rendered to U.S. authorities on September 12, 2001, has been unsuccessful in his calls for an inquiry into the events that led to his prolonged detention. See "America's Disappeared: Seeking International Justice for Immigrants Detained after September 11" American Civil Liberties Union (January 2004), online: Benatta Coalition for a Public Review <http://benamarbenatta.com/documents/un\%20report.pdf>.

177 Hill v. Hamilton-Wentworth Regional Police Services Board, 2007 SCC 41 at paras. 93-94. 
tion against torture applies to the culpable as well as the innocent victim - hardly the justice which a wrongfully accused seeks.

\section{CONCLUSION \& RECOMMENDATIONS}

In July 2005, the United Nations Committee against Torture expressed "its concerns at ... [t] he absence of effective measures to provide civil compensation to victims of torture in all cases." 178 Torture survivors who are also caught in Canada's anti-terrorism apparatus face a doubly difficult challenge: obtaining redress from the foreign torturer and accountability from the domestic actors responsible for setting in motion the events that led the accused to the torture chamber. Even by comparison to the wrongfully convicted, security certificate cases and listed organizations, where redress is not easily achieved, wrongfully accused like Almalki have very limited prospects for accessing meaningful justice. While Almalki has procedural access to a number of processes, they are all plagued with considerable difficulties, due in large part to the unique role played by national security confidentiality.

Administrative justice mechanisms are deficient or lacking altogether. Both the CPC and SIRC hold little promise of meeting the access to justice objectives described in Part II: access to a legal process and fair treatment once engaged with it; access to effective remedies for the multiple harms suffered; and access to a legal system that empowers and exonerates. The CPC in particular lacks sufficient procedural powers to meet the challenge of national security confidential information. Although SIRC has more robust review powers, its recent pronouncements in terrorism cases have gone unheeded by CSIS. Neither body is specifically mandated to provide prospective relief and compensation, as opposed to retrospective opinions on the propriety of official conduct. While Consular Affairs was found to have failed Almalki particularly badly, there is no review body auditing DFAIT's conduct. ${ }^{179}$

Commissions of Inquiry depend entirely on the discretion of the Executive in terms of their creation and terms of reference. Two notable inquiries involving four Canadians accused of ties to terrorism have now been conducted, a testament to the public importance of Canada's role in the fight against terrorism, as well as to the lack of other adequate arenas for investigation of such issues. Almalki's experience with the Iacobucci Inquiry reveals the shortcomings of the process; it did not fulfill the objectives of empowerment, redress, and accountability sought by those who have survived torture and who wish to clear their names.

Finally, the extent to which civil litigation can affect proper access to justice

178 Conclusions and recommendations of the Committee against Torture: Canada, UN CAT, 34th Sess., UN Doc. CAT/C/CR/34/CAN (July 2005) at 2-3. More generally, Article 3(a) of the International Covenant on Civil and Political Rights, 16 December 1966, 999 U.N.T.S, 171, Can. T.S. 1976 No. 47, 6 I.L.M. 368 (entered into force 23 March 1976, accession by Canada 19 May 1976) to which Canada is a signatory, imposes an obligation on states to "ensure that any person whose rights or freedoms ... are violated have an effective remedy."

179 Wesley Wark, "National Security and Human Rights Concerns in Canada: A Survey of Eight Critical Issues in the Post-9/11 Environment" [on file with author] at 30. 
remains to be seen, as Almalki's action wends its way through the courts. American experience in this regard is not promising, in light of the overriding concern for protecting state secrets. Analogous challenges under the Canada Evidence Act might await Almalki.

There are many reasons to be concerned about national security miscarriages of justice, not least of which is that we are still dealing with relatively new policies, laws and practices. Many scholars have been wrestling with the changes in the post 9/11 legal landscape; when gauging the impact of this new order, I believe it is important to assess the adequacy of accountability mechanisms and avenues for redress when our security apparatus wrongly targets individuals and causes them harm. In early 2009, we heard similar pleas for accountability. Both the Eminent Jurists Report on Terrorism, Counter Terrorism and Human Rights, ${ }^{180}$ and the report by the UN Special Rapporteur on the protection and promotion of human rights while countering terrorism ${ }^{181}$ have called for more meaningful civilian oversight of intelligence operations and for more effective remedies for victims of intelligence agencies' abuses. Access to justice for the wrongfully accused is a topic that falls squarely within this larger discussion about accountability.

By identifying the barriers to justice faced by the wrongfully accused in national security investigations, I hope to spark discussion about alternatives. Some that may be more promising are not yet in place, such as the oversight body recommended by Commissioner O'Connor, ${ }^{182}$ and an amendment to state immunity legislation that would enable Almalki to sue Syria in Canadian courts. ${ }^{183}$ Amendments to the Canada Evidence Act could be made that would replicate the relief currently available to defendants in criminal trials; that is, s. 38.14 could be extended to empower civil trial judges to find in favour of a plaintiff where the claim of national security privilege frustrates the litigation. A similar statutory power is currently under review by the U.S. Congress, in the State Secrets bill drafted in response to the Bush administration's repeated use of the privilege to block civil lawsuits arising out of extraordinary rendition and warrantless wiretapping policies. ${ }^{184}$

Special avenues of access to justice should also be explored. With respect to the wrongfully convicted, Archibald Kaiser has suggested that an Imprisonment Compensation Board be created both to investigate claims of wrongful convic-

180 International Commission of Jurists, “Assessing Damage, Urging Action” (Geneva 2009).

181 Report of the Special Rapporteur on the promotion and protection of human rights and fundamental freedoms while countering terrorism, Martin Scheinin, A/HRC/10/3 (4 February 2009).

182 A New Review Mechanism, supra note 74.

183 Craig Forcese, "De-Immunizing Torture: Reconciling Human Rights and State Immunity" (2007) McGill L.J. 127.

184 H.R. 984 ("A Bill to provide safe, fair, and responsible procedures and standards for resolving claims of state secret privilege."), online: Thomas Library of Congress <http://thomas.loc. gov/cgi-bin/query/z?c111:H.R.984>. Section 7(d) of the proposed legislation provides that the court, "after determining that privileged information, for which it is impossible to create a nonprivileged substitute, is necessary to decide a factual or legal issue or claim, the court shall weigh the equities and make appropriate orders in the interest of justice, such as striking the testimony of a witness, finding in favor of or against a party on a factual or legal issue to which the information is relevant, or dismissing a claim or counterclaim." 
tion and determine eligibility for, and quantum of, compensation. ${ }^{185}$ A similar specialized body should be considered in the national security context. Unlike SIRC, such a tribunal would have as its first priority the resolution of civilian complaints. Unlike the CPC, the new body would be empowered to view all privileged documents and summons witnesses. The new agency would also need access to all actors in the national security sphere, and not be limited in its jurisdiction to reviewing the actions of one government department or agency. Such an initiative would call for overwhelming political and popular support to be effective. It would require first, that we accept that miscarriages of justice populate our national security landscape, and that the state bears a concomitant responsibility to address these injustices.

As aptly stated in the Arar Report, "[a]n inordinately high price is paid when less than accurate intelligence is relied upon by state agencies, whether the field in question is that of security intelligence or law enforcement. Lives and security may be unreasonably or negligently placed at risk and, equally, lives may be ruined and reputations decimated by the ill-advised disclosure of or reliance upon erroneous or misleading personal information." ${ }^{186}$ A just society requires that meaningful remedies be made available to compensate those who pay this inordinately high price. ${ }^{187}$ To date, the Canadian legal system has been inadequate to the task.

Thus, access to justice for the wrongfully accused is crucial on multiple levels. For the individuals affected, barriers to procedural justice are yet another source of trauma. ${ }^{188}$ For society at large, the extent to which our laws and legal processes afford those who are "collateral damage" in the war on terror access to compensation and exoneration is a measure of our commitment to democracy. In effect, Almalki's continuing quest for justice "constitutes a barometer of [the] state's response to emergency, conflict and terrorism. The defence of access rights, and litigation related to them, can be seen as a litmus test of [our] society's ability to respond to extremity, and a place where the resistant quality of law is tested and defended." 189

185 Kaiser, supra note 29.

186 Arar Report, supra note 2 at 337 quoting Stanley Cohen, Privacy, Crime and Terror: Legal Rights and Security in a Time of Peril (Toronto: LexisNexis Butterworths, 2005) at 116.

187 An almost identical argument was made by Justice Sydney Robins in his Advisory Opinion on the Issue of Compensation for Steven Truscott: "We are all dependent upon the proper functioning of the criminal justice system and we must all share the burden of its errors. Through no fault of his own, Mr. Truscott suffered as a result of one of those errors. His loss should be borne by the community as a whole, and not by Mr. Truscott alone. The state has a moral obligation — an obligation that springs from a sense of justice and equity - to provide some redress to Mr. Truscott. The public's interest in the proper administration of justice - and, indeed, the public's conscience - demand that a payment be made." See Advisory Opinion, supra note 28.

188 As forcefully stated by the non-governmental organization REDRESS in its submissions to the InterAmerican Commission on Human Rights, "In certain cases, access to justice in and of itself can have a beneficial impact on the victim's healing process. In contrast, a denial of access to justice can compound existing trauma." See Brief Presented to the InterAmerican Commission on Human Rights by the REDRESS Trust In the Case of Khaled El Masri (31 March 2009) at 8, online: American Civil Liberties Union <http://www.aclu.org/pdfs/safefree/ redressamicusbrief_khaledelmasrivunitedstates_30march2009.pdf>

189 Ní Aoláin, supra note 24 at 92. 